\title{
Ionic basis of atrioventricular conduction: ion channel expression and sarcolemmal ion currents of the atrioventricular canal of the rainbow trout (Oncorhynchus mykiss) heart
}

\author{
Minna Hassinen $^{1}(\mathbb{D}) \cdot$ Irina Dzhumaniiazova ${ }^{2}$ Denis V. Abramochkin ${ }^{2,3,4} \mathbb{D} \cdot$ Matti Vornanen $^{1} \mathbb{D}$
}

Received: 6 September 2020 / Revised: 15 December 2020 / Accepted: 18 January 2021 / Published online: 11 February 2021

(c) The Author(s) 2021

\begin{abstract}
Atrioventricular (AV) nodal tissue synchronizes activities of atria and ventricles of the vertebrate heart and is also a potential site of cardiac arrhythmia, e.g., under acute heat stress. Since ion channel composition and ion currents of the fish AV canal have not been previously studied, we measured major cation currents and transcript expression of ion channels in rainbow trout (Oncorhynchus mykiss) AV tissue. Both ion current densities and expression of ion channel transcripts indicate that the fish AV canal has a characteristic electrophysiological phenotype that differs from those of sinoatrial tissue, atrium and ventricle. Two types of cardiomyocytes were distinguished electrophysiologically in trout AV nodal tissue: the one (transitional cell) is functionally intermediate between working atrial/ventricular myocytes and the other (AV nodal cell) has a less negative resting membrane potential than atrial and ventricular myocytes and is a more similar to the sinoatrial nodal cells in ion channel composition. The AV nodal cells are characterized by a small or non-existent inward rectifier potassium current $\left(I_{\mathrm{K} 1}\right)$, low density of fast sodium current $\left(I_{\mathrm{Na}}\right)$ and relatively high expression of T-type calcium channels (CACNA3.1). Pacemaker channel (HCN4 and HCN2) transcripts were expressed in the AV nodal tissue but $I_{\mathrm{f}}$ current was not found in enzymatically isolated nodal myocytes. The electrophysiological properties of the rainbow trout nodal cells are appropriate for a slow rate of action potential conduction ( $\operatorname{small} I_{\mathrm{Na}}$ ) and a moderate propensity for pacemaking activity (absence of $I_{\mathrm{K} 1}$ ).
\end{abstract}

Keywords Fish heart $\cdot$ Ion channel transcripts $\cdot$ Ion current densities $\cdot$ Electrical excitability $\cdot$ Atrioventricular nodal cells

\section{Introduction}

The activity of the vertebrate heart is controlled by rhythmic electrical impulses (action potentials, APs), which originate from the sinoatrial (SA) pacemaker. APs propagate at

Communicated by B. Pelster.

Matti Vornanen

matti.vornanen@uef.fi

1 Department of Environmental and Biological Sciences, University of Eastern Finland, P.O. Box 111, 80101 Joensuu, Finland

2 Department of Human and Animal Physiology, Lomonosov Moscow State University, Leninskiye Gory, 1, 12, Moscow, Russia

3 Laboratory of Cardiac Electrophysiology, National Medical Research Center for Cardiology, Moscow, Russia

4 Department of Physiology, Pirogov Russian National Research Medical University, Moscow, Russia alternating velocity through the histologically and functionally differentiated sections of the heart (Irisawa 1978; Stoyek et al. 2016). The rhythmic propagation pattern of electrical excitation (EE) is necessary for the synchrony of atrial and ventricular contractions and effective pump function of the heart (Billette and Tadros 2019).

The heart of teleost fishes consists of six consecutive histologically identifiable parts: Sinus venosus, atrium, atrioventricular (AV) canal, ventricle, conus arteriosus and bulbus arteriosus in the order from caudal to cranial direction (Icardo 2017). In fish hearts, the annular SA pacemaker at the junction between the sinus venosus and the atrium is the site of origin for EE (Yamauchi and Burnstock 1968; Haverinen and Vornanen 2007). From there, APs proceed first to the atrium and via the AV canal to the ventricle triggering sequential contractions of these two muscular chambers of the fish heart (McWilliam 1885; Keith and Flack 1907; Nair 1976; Arbel et al. 1977; Sedmera et al. 2003). In the atrial wall, the propagation of AP is fast, but it slows down sharply in the AV canal. This 
creates a delay that allows enough time for ventricular filling before the ventricle contracts (Meijler and Janse 1988; Sedmera et al. 2003; Milan et al. 2006; Haverinen et al. 2014; Stoyek et al. 2016; Billette and Tadros 2019). Another inherent characteristic of the vertebrate AV tissue is its ability to block AP conduction if the frequency of APs arriving from the atrial myocardium is high (Irisawa 1978; Billette and Tadros 2019). This prevents atrial tachycardia from triggering life-threatening arrhythmias in the ventricle(s). Finally, the AV nodal tissue can generate spontaneous APs and act as an auxiliary pacemaker if the SA pacemaker happens to fail (Meijler and Janse 1988a; Stoyek et al. 2016; Billette and Tadros 2019). When the slowly propagating impulse of the AV canal arrives to the ventricle, its rate accelerates again and induces a fast contraction of the ventricular myocardium (Sedmera et al. 2003). It is noteworthy that there is no histologically identifiable conductance pathway in the ventricle of the fish heart that is similar to the His-Purkinje system of the endothermic animals (Solc 2007).

The AV canal of the fish heart is homologous to the mammalian AV node (AVN) and is the sole conductance pathway for EE between the atrium and the ventricle (Solc 2007; Icardo and Colvee 2011; Jensen et al. 2012). It is a ring- or tube-shaped segment formed by myocardial and connective tissues to which the AV valves are attached (Santer and Cobb 1972; Icardo and Colvee 2011). The electric activity of the fish AV canal is poorly known and to our knowledge ion channel composition and ion currents of the fish AV cells have not been previously studied. This is a serious deficiency, because AV block is a common malfunction of the fish heart under different stresses and in response to environmental toxicants and medicinal drugs (McWilliam 1885; Arbel et al. 1977; Sarmah and Marrs 2016; Vornanen 2017; Cassar et al. 2019; Monteiro et al. 2020). In particular, it is known that at critically high temperatures, cardiac output in fish is compromised due to the functional AV block (Vornanen et al. 2014; Badr et al. 2016; Haverinen and Vornanen 2020). Furthermore, understanding the function of the fish AV canal is vital for the use of zebrafish as an animal model of the human heart. In particular, because zebrafish is suggested as a useful translational model for preclinical screening of cardiovascular drug molecules and safety pharmacology of environmental toxicants (Barros et al. 2008). To this end, our objective was to characterize the ion $\left(\mathrm{Na}^{+}, \mathrm{K}^{+}, \mathrm{Ca}^{2+}\right)$ channel composition of the fish $\mathrm{AV}$ tissue at transcript level and to measure the density of major sarcolemmal ion $\left(\mathrm{Na}^{+}, \mathrm{K}^{+}, \mathrm{Ca}^{2+}\right)$ currents in different cell types of the $\mathrm{AV}$ canal. We used quantitative PCR and single cell patch clamp to quantitate ion channel expression and ion current densities, respectively, in the AV canal of the rainbow trout (Oncorhynchus mykiss).

\section{Materials and methods}

\section{Animals}

Rainbow trout (Oncorhynchus mykiss) were obtained from a local fish farm (Kontiolahti, Finland). Fish with two different sizes were used: smaller ones for the histological staining $(28.08 \pm 5.63 \mathrm{~g}, n=6)$ to allow efficient penetration of fixative to the heart, and bigger fish $(299.68 \pm 49.79 \mathrm{~g})$ for the quantitative PCR $(n=5)$ and electrophysiological recordings $(n=8)$ to make it easier to obtain enough material from the small SA and AV regions. In the laboratory, the fish were reared in 500-L stainless steel tanks at $+12{ }^{\circ} \mathrm{C}$ in $12: 12 \mathrm{~h}$ light:dark photoperiod and fed five times per week commercial fish food (Ewos, Turku Finland). All experiments were made with the consent of the national committee for animal experimentation (permission ESAVI/8877/2019).

\section{Histology}

Fish was stunned by a quick blow to the head and killed by cutting the spine immediately behind the head. The heart was dissected and rinsed in phosphate-buffered saline before fixation in Bouin's fixative (RAL Diagnostics, Martillac, France) for at least $24 \mathrm{~h}$. The hearts were dehydrated in graded series of ethanol, cleared in xylene, and embedded in UltraPar paraffin (J.T.Baker, Deventer, Holland). Sections $(7 \mu \mathrm{m})$ were cut using Leica RM2165 microtome (Leica Microsystems, Nußloch, Germany), attached on SuperFrost Plus slides (VWR International, Leuven, Belgium) and stained with Masson's trichrome. Stained sections were photographed using Leica DMi1 (Leica Microsystems, Wetzlar, Germany).

\section{Whole-cell patch clamp}

For the isolation of myocytes of AV canal, ventricle and atrium, the cannula was inserted in the ventricle through the aortic bulb and the heart was retrogradely perfused for 10-12 min with proteolytic enzymes (collagenase type 1A, $0.75 \mathrm{mg} \mathrm{ml}^{-1}$; trypsin type IX, $0.5 \mathrm{mg} \mathrm{ml}^{-1}$ both from Sigma and fatty acid free bovine serum albumin from Serva, $0.75 \mathrm{mg} \mathrm{ml}^{-1}$ ) as previously described in detail (Vornanen 1997; Haverinen and Vornanen 2007). Immediately upon completion of the perfusion, the AV region was excised, minced, and incubated in the enzyme solution for additional $20 \mathrm{~min}$. After the enzymatic digestion, the tissue was triturated with a Pasteur pipette to release single myocytes. Cells were stored up to $8 \mathrm{~h}$ at $+5^{\circ} \mathrm{C}$ in the cardioplegic low- $\mathrm{Na}^{+}$solution containing $\left(\mathrm{mmol} \mathrm{L}^{-1}\right) \mathrm{NaCl} 100, \mathrm{KCl} 10$, $\mathrm{KH}_{2} \mathrm{PO}_{4} \cdot 2 \mathrm{H}_{2} \mathrm{O} 1.2, \mathrm{MgSO}_{4} \cdot 7 \mathrm{H}_{2} \mathrm{O} 4$, taurine 50, glucose 10 
and Hepes 10 at $\mathrm{pH}$ of 6.9. Ventricular and atrial myocytes were released from the tissue by mincing and triturating of ventricular and atrial muscle, respectively, immediately after the 10-12 min whole heart perfusion. Atrial and ventricular myocytes were used for comparison with AV canal myocytes.

A small aliquot of myocyte suspension was placed in the experimental chamber (RCP-10 T, Dagan, Maryland, MI, USA, volume $150 \mu \mathrm{L}$ ) and superfused at the rate of about $1.5 \mathrm{ml} \mathrm{min}^{-1}$ with the external $\mathrm{K}^{+}$-based physiological saline solution containing (in $\mathrm{mmol} \mathrm{L}^{-1}$ ) $\mathrm{NaCl} 150, \mathrm{KCl}$ 5.4, $\mathrm{NaH}_{2} \mathrm{PO}_{4} 0.4, \mathrm{MgSO}_{4} 1.5, \mathrm{CaCl}_{2} 1.8$, glucose 10 and Hepes 10 at pH 7.7 (adjusted with $\mathrm{KOH}$ ). Temperature of the external solution was regulated to $+12{ }^{\circ} \mathrm{C}$ using a Peltier device (TC-100, Dagan, Maryland, MI, USA). Ionic currents were recorded in the voltage clamp mode of the whole-cell patch clamp technique using the Axopatch 1-D amplifier (Molecular Devices, CA, USA) and the pClamp 8.2 software package. Patch pipettes of $1.5-2.5 \mathrm{M} \Omega$ resistance were pulled from borosilicate glass (Hilgenberg $\mathrm{GmbH}$, Germany). Pipette capacitance, access resistance and whole cell capacitance were routinely cancelled.

For recording of $\mathrm{K}^{+}$currents, the pipettes were filled with $\mathrm{K}^{+}$-based electrode solution containing (in $\mathrm{mmol} \mathrm{l}^{-1}$ ): $140 \mathrm{KCl}, 1 \mathrm{MgCl}_{2}$, 5 EGTA, 4 MgATP, $0.3 \mathrm{Na}_{2}$ GTP and 10 HEPES with $\mathrm{pH}$ adjusted to 7.2 with $\mathrm{KOH}$ (at $+20{ }^{\circ} \mathrm{C}$ ). The standard external $\mathrm{K}^{+}$-based physiological solution was used. Similar conditions were used for measurements of membrane potential in the current clamp mode. For recording of $\mathrm{Ca}^{2+}$ currents, $\mathrm{KCl}$ in both external and pipette solutions was substituted with equimolar concentration of $\mathrm{CsCl}$. The external solution for $\mathrm{I}_{\mathrm{Na}}$ recordings contained less $\mathrm{Na}^{+}$to reduce the driving force for $\mathrm{Na}^{+}$influx (in $\mathrm{mmol}^{-1}$ ): $20 \mathrm{NaCl}$, $120 \mathrm{CsCl}, 1 \mathrm{MgCl}_{2}, 0.5 \mathrm{CaCl}_{2}, 10$ glucose, 10 HEPES, pH adjusted to 7.7 with $\mathrm{CsOH}$. The pipette solution for $\mathrm{I}_{\mathrm{Na}}$ contained (in mmol $\mathrm{l}^{-1}$ ): $5 \mathrm{NaCl}, 130 \mathrm{CsCl}, 1 \mathrm{MgCl}_{2}, 5$ EGTA, $5 \mathrm{Mg}_{2}$ ATP, 5 HEPES, pH adjusted to 7.2 with $\mathrm{CsOH}$ (Vornanen et al. 2011).

\section{Quantitative PCR}

Transcripts (mRNA) of 41 ion channel genes and 1 transcription factor were measured from 5 different tissue sections of the trout heart. To this end, the heart was excised and placed in cold physiological saline solution. A thin (about $2 \mathrm{~mm}$ in width) tissue ring was cut out from the atrioventricular junction so that the whole AV canal was included. This piece of tissue was divided in the middle into two parts, the atrial side (AV-atr) and the ventricular (AV-ven) side. This was done, because the fish AV canal is not a homogenous and sharply delimited structure, which could be dissected clean from the surrounding atrial and ventricular muscles. Gene expression was separately measured for $\mathrm{AV}$-atr and
$\mathrm{AV}$-ven. In addition to $\mathrm{AV}$-atr and $\mathrm{AV}$-ven, gene expression was measured from atrial and ventricular tissue and SA pacemaker. The fish cardiac pacemaker (hereafter called SA node or SAN) is an annular tissue mass at the border between sinus venosus and the atrium. SAN was obtained as a thin ring of tissue from this border zone. Tissue pieces (SAN, atrium, AV-atr, AV-ven and ventricle) were quickly frozen in liquid nitrogen and stored at $-80{ }^{\circ} \mathrm{C}$ until used in experiments. Total RNA was extracted by TRI Reagent Solution (Thermo Scientific, Vilnius, Lithuania) and stored at $-80^{\circ} \mathrm{C}$. The integrity and quantity of RNA was assessed by agarose gel electrophoresis and NanoDrop ND-1000 Spectrophotometer (NanoDrop Technologies, Wilmington, DE, USA), respectively. An aliquot of $1.5 \mu \mathrm{g}$ of total RNA was treated with RNase-free DNase (Thermo Scientific) and converted to cDNA by Maxima H Minus First Strand cDNA Synthesis Kit (Thermo Scientific) using a mixture of random hexamers and oligo(dT $)_{18}$ primers. From each DNase-treated sample, a control reaction containing all other reaction components except RT enzyme was produced. Primer pairs were designed using Primer3 software (http://bioinfo.ut.ee/prime r3-0.4.0/primer3/). All primer pairs were tested using rainbow trout genomic DNA as the template, and only primers giving 95-105\% efficacy were chosen. Amplification was performed as triplicates from each sample using Maxima SYBR Green qPCR Master Mix (Thermo Scientific), primers presented in Table 1 and AriaMx Real-Time PCR System (Agilent Technologies Inc., Santa Clara, CA, USA) with the following cycling conditions: initial denaturation and enzyme activation at $+95{ }^{\circ} \mathrm{C}$ for 10 min followed by 40 cycles of denaturation at $+95^{\circ} \mathrm{C}$ for $15 \mathrm{~s}$, annealing at +57 to $58{ }^{\circ} \mathrm{C}$ for $30 \mathrm{~s}$, and extension at $+72{ }^{\circ} \mathrm{C}$ for $30 \mathrm{~s}$. After amplification, a melting curve analysis was performed by rising the temperature from +65 to $+95^{\circ} \mathrm{C}$ and reading the fluorescence after every $0.5^{\circ} \mathrm{C}$ increase to check the specificity of amplification. A couple of qPCR products amplified with each primer pair was run on an agarose gel to check the length and specificity of the amplification. Comparative quantification was used to calculate the mRNA level of the genes of interest. The mRNA expression of the studied genes was normalized to the transcript abundance of reference gene DnaJA2 using $\Delta \mathrm{Ct}$ method (Vornanen et al. 2005; Hassinen et al. 2015).

\section{Statistics}

The results are represented as means \pm s.e.m. Normality of distribution was tested using Shapiro-Wilk test and if variables were not normally distributed, logarithmic transformations were made to get the data normally distributed before statistical testing. Equality of variances was checked and comparisons between mRNA amounts were performed using one-way ANOVA followed with paired comparisons using 
Table 1 Accession numbers (GenBank) and primers for the genes studied in qPCR. Amplicon length, melting temperature of the product and annealing temperature used in qPCR are represented

\begin{tabular}{|c|c|c|c|c|c|c|}
\hline Gene & Protein & Accession no & Primers $\left(5^{\prime}-3^{\prime}\right)$ & Product (bp) & $\begin{array}{l}\mathrm{Tm} \\
\left({ }^{\circ} \mathrm{C}\right)\end{array}$ & $\begin{array}{l}\text { Annealing } \\
\text { temp. }\left({ }^{\circ} \mathrm{C}\right)\end{array}$ \\
\hline CACNA1C & Cav1.2 & XM_021595819 & $\begin{array}{l}\text { F: tgacatgaccatcgaggaga } \\
\text { R: ctgttgcagtgcatgtaggg }\end{array}$ & 105 & 82.0 & 58 \\
\hline CACNA1Daa & Cav1.3aa & AF450282 & $\begin{array}{l}\text { F: cctgcataggagtacagctct } \\
\text { R: gcctctctctcttttggatggc }\end{array}$ & 144 & 74.5 & 57 \\
\hline CACNA1Dab & Cav1.3ab & XM_021567482 & $\begin{array}{l}\text { F: ctgcataggggtgcagctc } \\
\text { R: gccacactctcttatggacgaa }\end{array}$ & 143 & 83.0 & 58 \\
\hline CACNA1Dba & Cav1.3ba & XM_021614407 & $\begin{array}{l}\text { F: ttcgctaccctaccgttcgt } \\
\text { R: ttgacactccttacgggaca }\end{array}$ & 147 & 81.5 & 58 \\
\hline CACNA1Dbb & Cav1.3bb & XM_021564469 & $\begin{array}{l}\text { F: ttctgtacccaaccatccgc } \\
\text { R: ttgaaactccetatggggca }\end{array}$ & 147 & 80.5 & 58 \\
\hline CACNA1Ga & Cav3.1a & XM_021575364 & $\begin{array}{l}\text { F: cgtcgagctcggcaactat } \\
\text { R: ggacttcatgtccatctgacac }\end{array}$ & 132 & 83.5 & 58 \\
\hline CACNA1Gb & Cav3.1b & XM_021567299 & $\begin{array}{l}\text { F: gagaaagagtaggaagacttcgg } \\
\text { R: tctcacactccegttcactaa }\end{array}$ & 130 & 78.5 & 58 \\
\hline CACNA1Ha & Cav3.2a & XM_021592899 & $\begin{array}{l}\text { F: ccgtctgtaacaggggagt } \\
\text { R: gtcctcctccatgtcatcgt }\end{array}$ & 106 & 80.5 & 58 \\
\hline CACNA1Hb & Cav3.2b & XM_021593501 & $\begin{array}{l}\text { F: gcggaggagtcaatcaagtg } \\
\text { R: tctgattggtccaggaggtc }\end{array}$ & 120 & 82.5 & 58 \\
\hline CACNA1Ia & Cav3.3a & XM_021625686 & $\begin{array}{l}\text { F: agtgactcccagggttcaga } \\
\text { R: cctcctcggctactgaactg }\end{array}$ & 109 & 84.5 & 58 \\
\hline CACNA1Ib & Cav3.3b & XM_021570408 & $\begin{array}{l}\text { F: ccgtagtggatcacagtgga } \\
\text { R: cctgtgcaggtgagtacagc }\end{array}$ & 102 & 82.0 & 58 \\
\hline HCN1a & HCN1a & NM_001124318 & $\begin{array}{l}\text { F: cagccacctctttgacctaca } \\
\text { R: agttcaggttgccgtggat }\end{array}$ & 129 & 87.5 & 58 \\
\hline HCN1b & HCN1b & XM_021603242 & $\begin{array}{l}\text { F: agtcatccgcccatttaacatg } \\
\text { R: gagacactggggacagggta }\end{array}$ & 115 & 86.0 & 58 \\
\hline HCN2aa & HCN2aa & XM_021588920 & $\begin{array}{l}\text { F: cgtgtggctttcgcctcta } \\
\text { R: ggctatcgatcaaatccttgttgg }\end{array}$ & 118 & 86.5 & 57 \\
\hline $\mathrm{HCN} 2 \mathrm{ab}$ & HCN2ab & XM_021614280 & $\begin{array}{l}\text { F: cctctggcgcatccagga } \\
\text { R: gcgagtgggtgcttttgtgt }\end{array}$ & 142 & 86.5 & 58 \\
\hline $\mathrm{HCN} 2 \mathrm{ba}$ & $\mathrm{HCN} 2 \mathrm{ba}$ & XM_021589263 & $\begin{array}{l}\text { F: actgttacatcgctggggatg } \\
\text { R: ggaggctggctataaactcactc }\end{array}$ & 112 & 84.0 & 58 \\
\hline $\mathrm{HCN} 2 \mathrm{bb}$ & $\mathrm{HCN} 2 \mathrm{bb}$ & XM_021601253 & $\begin{array}{l}\text { F: gggacaggcatgggtgc } \\
\text { R: tggtcggctttggagtccttt }\end{array}$ & 113 & 84.5 & 58 \\
\hline HCN3a & HCN3a & XM_021571553 & $\begin{array}{l}\text { F: atggaggcttcggatgtgta } \\
\text { R: ctgatggatgtagcggatgaag }\end{array}$ & 116 & 84.5 & 57 \\
\hline $\mathrm{HCN} 3 \mathrm{~b}$ & $\mathrm{HCN} 3 \mathrm{~b}$ & $\begin{array}{l}\text { XM_021619039 } \\
\text { XM_021598239 }\end{array}$ & $\begin{array}{l}\text { F: ggctggactcagaggtttaca } \\
\text { R: ctggtggatgtagcgtatgagt }\end{array}$ & 115 & 84.5 & 57 \\
\hline HCN4a & HCN4a & XM_021607247 XM_021585508 & $\begin{array}{l}\text { F: agctactggtggagcaatgg } \\
\text { R: gggggctgatactacaacca }\end{array}$ & 125 & 81.0 & 58 \\
\hline $\mathrm{HCN} 4 \mathrm{ba}$ & HCN4ba & XM_021580609 & $\begin{array}{l}\text { F: ctgtccctacacgaccacaa } \\
\text { R: acctacaacgectccaacac }\end{array}$ & 127 & 83.0 & 58 \\
\hline $\mathrm{HCN} 4 \mathrm{bb}$ & $\mathrm{HCN} 4 \mathrm{bb}$ & XM_021601191 & $\begin{array}{l}\text { F: tccagaccgtctctctccat } \\
\text { R: gaggtgtgacgtgggagttt }\end{array}$ & 104 & 80.0 & 58 \\
\hline $\begin{array}{l}\text { ISL1 } \\
\text { ISL1L }\end{array}$ & $\begin{array}{l}\text { ISL1 } \\
\text { ISL1L }\end{array}$ & $\begin{array}{l}\text { XM_021622253 } \\
\text { XM_021605098 }\end{array}$ & $\begin{array}{l}\text { F: aaaccagatccacgaccagt } \\
\text { R: cagtaggttttccegtctcg }\end{array}$ & 138 & 82.0 & 58 \\
\hline $\mathrm{KCNH} 2 \mathrm{aa}$ & Kv11.1aa & XM_021589368 & $\begin{array}{l}\text { F: agtttgaggggctgaggaa } \\
\text { R: agcactgctgatgttgagga }\end{array}$ & 143 & 80.5 & 58 \\
\hline $\mathrm{KCNH} 2 \mathrm{ab}$ & $\mathrm{Kv} 11.1 \mathrm{ab}$ & XM_021613401 & $\begin{array}{l}\text { F: gcctttccaagtcctgtgag } \\
\text { R: aggaggagtcttggggagag }\end{array}$ & 113 & 82.0 & 58 \\
\hline $\mathrm{KCNH} 2 \mathrm{ba}$ & Kv11.1ba & XM_021622309 & $\begin{array}{l}\text { F: acaagtatgtcacagccctctat } \\
\text { R: gagcatgacacagatggagaat }\end{array}$ & 112 & 80.5 & 58 \\
\hline
\end{tabular}


Table 1 (continued)

\begin{tabular}{|c|c|c|c|c|c|c|}
\hline Gene & Protein & Accession no & Primers $\left(5^{\prime}-3^{\prime}\right)$ & Product (bp) & $\begin{array}{l}\mathrm{Tm} \\
\left({ }^{\circ} \mathrm{C}\right)\end{array}$ & $\begin{array}{l}\text { Annealing } \\
\text { temp. }\left({ }^{\circ} \mathrm{C}\right)\end{array}$ \\
\hline $\mathrm{KCNH} 2 \mathrm{bb}$ & Kv11.1bb & XM_021562719 & $\begin{array}{l}\text { F: agtacgtgacggcactctac } \\
\text { R: gcatgacgcagatggaaaag }\end{array}$ & 108 & 81.5 & 58 \\
\hline KCNH6a & $\mathrm{Kv} 11.2 \mathrm{a}$ & XM_021558455 & $\begin{array}{l}\text { F: ttcctgctcaacgagatgga } \\
\text { R: tggtccggaagttgatgaga }\end{array}$ & 127 & 83.5 & 58 \\
\hline KCNH6b & $\mathrm{Kv} 11.2 \mathrm{~b}$ & XM_021567337 & $\begin{array}{l}\text { F: ttcctattggatgagcgtgg } \\
\text { R: gtgcgaaagttgatcccgata }\end{array}$ & 125 & 82.5 & 58 \\
\hline KCNH7aa & Kv11.3aa & XM_021571238 & $\begin{array}{l}\text { F: taagcagtccetcccacaag } \\
\text { R: ccgcgtgtcattggtgta }\end{array}$ & 142 & 88.0 & 58 \\
\hline $\mathrm{KCNH} 7 \mathrm{ab}$ & Kv11.3ab & XM_021608684 & $\begin{array}{l}\text { F: ttactacagagtcaatgcggg } \\
\text { R: cctcttagctcttccgacet }\end{array}$ & 107 & 78.0 & 58 \\
\hline KCNH7ba & Kv11.3ba & XM_021597081 & $\begin{array}{l}\text { F: gtatggagctgctgtgctaatg } \\
\text { R: tcttgccaatggagacaccc }\end{array}$ & 155 & 81.5 & 58 \\
\hline $\mathrm{KCNH} 7 \mathrm{bb}$ & $\mathrm{Kv} 11.3 \mathrm{bb}$ & XM_021579952 & $\begin{array}{l}\text { F: cggagcggctgtactcatc } \\
\text { R: tcttgccaatggatacccca }\end{array}$ & 152 & 82.0 & 58 \\
\hline $\mathrm{KCNJ} 2 \mathrm{a}$ & Kir2.1a & XM_021576592 XM_021581081 & $\begin{array}{l}\text { F: ggcgctgactaacaaagagga } \\
\text { R: tctagtggcacagtggcetg }\end{array}$ & 117 & 83.0 & 58 \\
\hline $\mathrm{KCNJ} 2 \mathrm{~b}$ & Kir2.1b & XM_021559076 & $\begin{array}{l}\text { F: gaggtggccettgaaaaagt } \\
\text { R: tgttgcgttctcaatgtcgttc }\end{array}$ & 129 & 80.0 & 58 \\
\hline $\mathrm{KCNJ} 12 \mathrm{a}$ & Kir2.2a & $\begin{array}{l}\text { XM_021565106 } \\
\text { XM_021575489 }\end{array}$ & $\begin{array}{l}\text { F: acctgtacaaggtggattactc } \\
\text { R: acagaaggagttggaggtgg }\end{array}$ & 122 & 81.5 & 58 \\
\hline $\mathrm{KCNJ} 12 \mathrm{~b}$ & Kir2.2b & $\begin{array}{l}\text { XM_021599878 } \\
\text { XM_021624360 }\end{array}$ & $\begin{array}{l}\text { F: gccagtacaaagtggattacg } \\
\text { R: taggatccttgtcctcgtcc }\end{array}$ & 111 & 82.0 & 58 \\
\hline KCNJ14 & Kir2.4 & XM_021622272 & $\begin{array}{l}\text { F: tgctacgagaacgaagtagcc } \\
\text { R: ttagtgtgggtgggttgtga }\end{array}$ & 122 & 85.0 & 58 \\
\hline SCN4Aa & Nav1.4a & XM_021565351 & $\begin{array}{l}\text { F: cgctccaagaggcagataag } \\
\text { R: acccagccaattccatctct }\end{array}$ & 130 & 83.5 & 57 \\
\hline SCN4Aba & Nav1.4ba & EF203231 & $\begin{array}{l}\text { F: tcagctggttgggatggtc } \\
\text { R: aacaaattcccaaaccaggg }\end{array}$ & 127 & 82.0 & 57 \\
\hline SCN4Abb & Nav1.4bb & XM_021624591 & $\begin{array}{l}\text { F: ttagccggttgggacagtg } \\
\text { R: agaattccccaaccaagget }\end{array}$ & 125 & 81.5 & 57 \\
\hline SCN5LAa & Nav1.5a & XM_021614310 & $\begin{array}{l}\text { F: tcatcatccagcgctgttac } \\
\text { R: tgcaagttcaggttggtctg }\end{array}$ & 103 & 80.5 & 57 \\
\hline SCN5LAba & Nav1.5ba & XM_021562569 & $\begin{array}{l}\text { F: tggatgctctcaaacagcag } \\
\text { R: cgacacatcctcctgcttg }\end{array}$ & 110 & 81.5 & 57 \\
\hline SCN5LAbb & Nav1.5bb & XM_021622315 & $\begin{array}{l}\text { F: ggacatgtccgcagcagtc } \\
\text { R: cctcttgtccgtggagcttt }\end{array}$ & 127 & 83.0 & 57 \\
\hline DnaJA2 & DnaJA2 & XM_021585925 & $\begin{array}{l}\text { F: ttgtaatggagaaggtgagg } \\
\text { R: tgggccgctctcttgtatgt }\end{array}$ & 231 & 83.5 & $57-58$ \\
\hline
\end{tabular}

Gene paralogues are named as -a and -b. If more than two paralogues exist for the same gene, paralogues are named as -aa, -ab, -ba and -bb

Tukey's (equal variances) or Dunnett's T3 (unequal variances) post hoc tests. The densities of ionic currents were compared using two-way ANOVA with Tukey's multiple comparisons test. Student's $t$ test was used to compare the capacitances of nodal and transitional cells. A $p$ value $<0.05$ was deemed to be statistically significant.

\section{Results}

\section{Histology of AV canal and AV myocytes}

In trout heart, the AV region consists of a layer of compact 

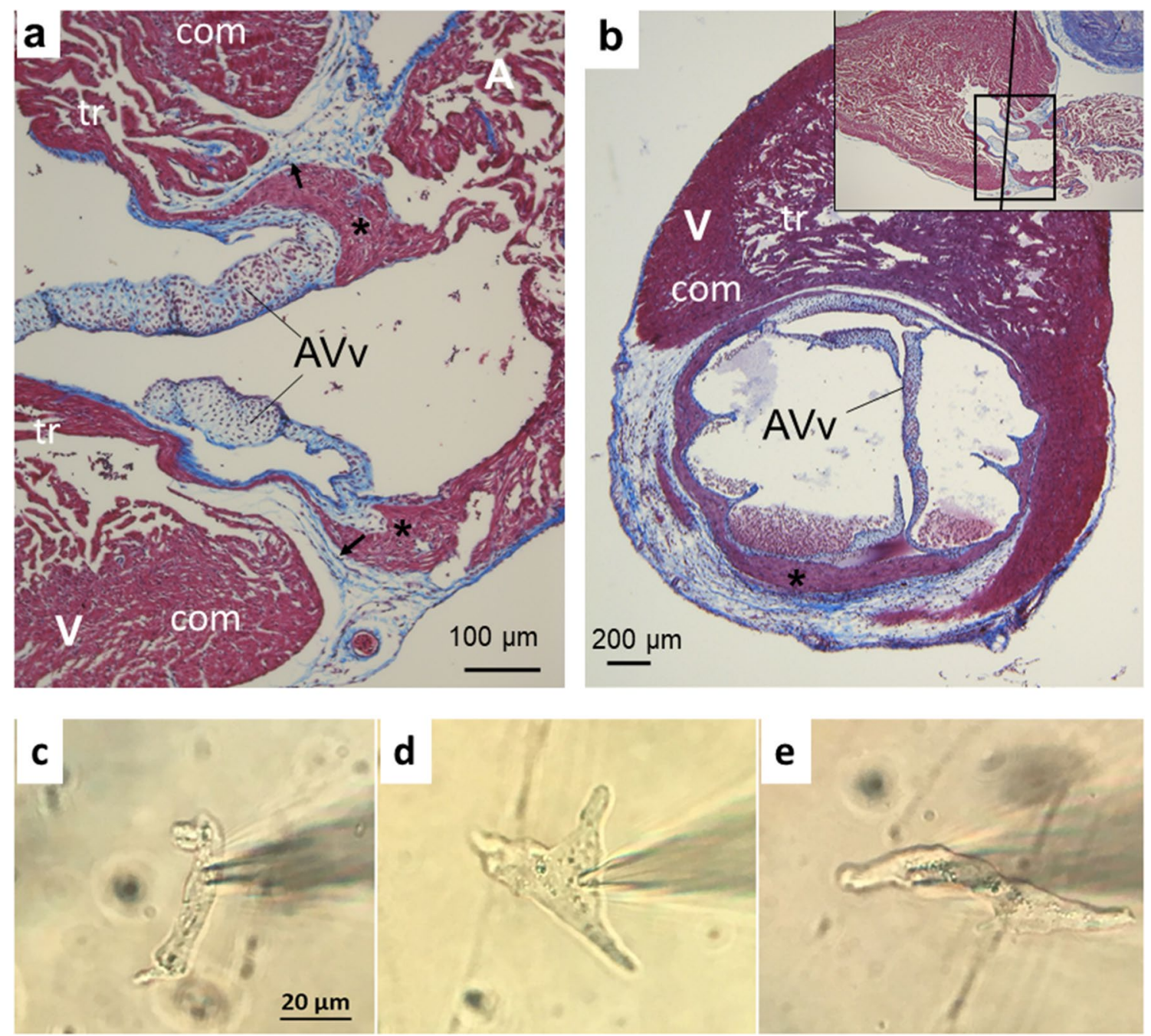

Fig. 1 Histological characteristics of AV canal and AV cell types of rainbow trout heart. a, b Tissue sections stained with Masson's trichrome. a Longitudinal section shows that the AV region is formed by a compact myocardium. It is continuous with the atrial muscle, surrounded laterally on both sides by connective tissue, and extends to endocardial trabeculae of the ventricle as a thin layer. The arrows indicate that the AV tissue is isolated from the compact ventricular myocardium by connective tissue. b Transverse section shows that the

myocardium which is surrounded by a collagen-rich connective tissue from both sides (Fig. 1). On the atrial side, the AV tissue forms a robust muscle strand that is continuous with the atrial tissue (Fig. 1a). On the opposite side, the AV canal advances as a thin muscle to the ventricle forming a delicate muscle layer around the AV canal (Fig. 1b). The AV tissue supports AV valves which are completely composed of a collagenous connective tissue. The connective tissue extends from the base of the valves as a thin annular layer to the ventricular side and insulates the AV muscle from the lumenal side of the ventricle. Another strand of connective tissue, starting from the boundary zone between the atrium and the ventricle,
$\mathrm{AV}$ muscle forms a thin ring or tube that is surrounded on both sides by connective tissue. The inset in the upper corner shows the enlarged tissue area in the (a) and the sectioning level of the tissue in the (b). A atrium, $A V v$ atrioventricular valves, $V$ ventricle; com, compact myocardium, $t r$ endocardial trabeculae, *AV myocardium; arrowhead, connective tissue. c, $\mathbf{d}$ Photomicrographs of morphological cell types of the rainbow trout AV canal: $\mathbf{c}$ spindle-shaped nodal AV cell, $\mathbf{d}$ staror spider-shaped nodal AV cell and $\mathbf{e}$ transitional AV cell

surrounds the AV muscle from the outside. Owing to these two layers, the AV muscle is laterally surrounded by connective tissue on both sides. Notably, the AV muscle is connected with spongious ventricular trabeculae but isolated from the compact ventricular myocardium by a connective tissue layer.

Based on electrophysiological characteristics, cardiac myocytes of the rainbow trout AV canal were separated in two groups called as "nodal" and "transitional" AV cells, respectively. While the nodal AV myocytes are either star, spider or short spindle shaped (Fig. 1c, d), the transitional AV cells are always spindle shaped (Fig. 1e). Despite a visually smaller size, the nodal cells were significantly larger 
by electrophysiological measurements than the transitional cells with a capacitive cell size of $30.7 \pm 1.87 \mathrm{pF}(n=27)$ and $20.1 \pm 0.79 \mathrm{pF}(n=35)(p<0.0001)$, respectively. Moreover, both the nodal and transitional cells usually lacked clear cross striations.

\section{Membrane potential and inward rectifier $\mathrm{K}^{+}$current}

In some myocytes isolated from the AV region, the membrane potential was measured in the current clamp mode. While transitional AV cells had a stable negative membrane potential $\left(V_{\text {rest }}\right)(-77.6 \pm 1.45 \mathrm{mV}, n=18)$, nodal $\mathrm{AV}$ cells seemed to be strongly depolarized $(-17.9 \pm 2.2 \mathrm{mV}$, $n=7$ ) and demonstrated irregular fluctuations of membrane potential (not shown). Consistent with these observations, the background inward rectifier $\mathrm{K}^{+}$current $\left(I_{\mathrm{K} 1}\right)$, which is the main determinant of $V_{\text {rest }}$, had a very low density $\left(-0.49 \pm 0.14 \mathrm{pA} \mathrm{pF}^{-1}\right.$ at $\left.-120 \mathrm{mV}\right)$ in nodal cells and similar to that of atrial myocytes $\left(-1.07 \pm 0.41 \mathrm{pA} \mathrm{pF}^{-1}\right.$ at $-120 \mathrm{mV} ; p>0.05$ ) (Fig. 2a, b). The depolarized membrane potential of nodal AV cells is partly an artifact due to the imperfect voltage measuring of the whole-cell current clamp in myocytes with low $\mathrm{I}_{\mathrm{K} 1}$ density: ion leakage between cell membrane and pipette partly offsets the repolarizing effect of $\mathrm{I}_{\mathrm{K} 1}$. In contrast to the nodal cells, the transitional cells demonstrated a large $\mathrm{I}_{\mathrm{K} 1}$. However, the inward and outward components of the $\mathrm{I}_{\mathrm{K} 1}$ in the transitional cells were not quite as large as in the ventricular cells $(p<0.05)$ (Fig. 2b). Thus, nodal cells could be electrophysiologically distinguished from transitional cells based on their small $\mathrm{I}_{\mathrm{K} 1}$ and less negative $V_{\text {rest }}$.

Noteworthy, hyperpolarization of both types of AV cells to -80 to $-160 \mathrm{mV}$ from the holding potential of $-35 \mathrm{mV}$ did not induce any inward time-dependent current which would be considered as the pacemaker current $\left(I_{\mathrm{f}}\right)$.

\section{A delayed rectifier $\mathrm{K}^{+}$current}

In rainbow trout atrial and ventricular myocytes, the delayed rectifier $\mathrm{K}^{+}$current mainly consists of the rapid component, $I_{\mathrm{Kr}}$ (Hassinen et al. 2008). However, the presence of a small slow delayed rectifier, $I_{\mathrm{Ks}}$, cannot be excluded, since it has been found in zebrafish and crucian carp myocytes (Hassinen et al. 2011; Abramochkin et al. 2018). Therefore, we use the term delayed rectifier $\left(\mathrm{I}_{\mathrm{K}}\right)$ for the time-dependent $\mathrm{K}^{+}$outward current induced by depolarization. In both transitional and nodal AV cells, depolarization induced an outward $\mathrm{I}_{\mathrm{K}}$ with a prominent tail current (Fig. 2c, d). The density of $\mathrm{I}_{\mathrm{K}}$ was similar in transitional and nodal cells, but at $+40 \mathrm{mV}$, the current was slightly larger in transitional than nodal cells $(p<0.05)$. In both types of AV myocytes, $\mathrm{I}_{\mathrm{K}}$ was smaller than in ventricular myocytes and much smaller than in atrial myocytes $(p<0.001)$ (Fig. 2e).

\section{$\mathrm{Na}^{+}$and $\mathrm{Ca}^{2+}$ currents}

All studied transitional AV cells had a distinct TTX-sensitive $\mathrm{Na}^{+}$current, $I_{\mathrm{Na}}$ (Fig. 3a), albeit it was smaller than $I_{\mathrm{Na}}$ of atrial and ventricular myocytes (Fig. 3e). In transitional cells, $\mathrm{I}_{\mathrm{Na}}$ had a typical current-voltage $(I-V)$ relationship of $\mathrm{I}_{\mathrm{Na}}$ with a peak current at $-20 \mathrm{mV}$. Unlike the transitional cells, the nodal myocytes completely lacked $\mathrm{I}_{\mathrm{Na}}$.

In addition to the TTX-sensitive $\mathrm{I}_{\mathrm{Na}}$, a relatively fast TTX-resistant $(0.3 \mu \mathrm{M})$ inward current could be observed in nodal AV cells during depolarization to membrane voltages more positive than $-50 \mathrm{mV}$ (Fig. 4). When $200 \mu \mathrm{M}$ nifedipine (a blocker of $\mathrm{Ca}^{2+}$ currents) was included in the external saline, this current was eliminated. Thus, this kinetically fast inward current is a $\mathrm{Ca}^{2+}$ current $\left(\mathrm{I}_{\mathrm{Ca}}\right)$ (Fig. $4 \mathrm{~b})$. Furthermore, the $I-V$ curve of the nodal $I_{\mathrm{Ca}}$ was characterized by two inward peaks: the first at about $-20 \mathrm{mV}$ and the second at about $+10 \mathrm{mV}$ (Fig. 4c). Application of $10 \mu \mathrm{M}$ nifedipine, the standard concentration used for inhibiting of the L-type $\mathrm{Ca}^{2+}$ current $\left(I_{\mathrm{CaL}}\right)$, did not completely abolish the nodal $\mathrm{I}_{\mathrm{Ca}}$. However, at a slightly higher concentration $(20 \mu \mathrm{M})$, nifedipine abolished the late peak at $+10 \mathrm{mV}$ while the early peak remained almost untouched (Fig. 4a). The early peak could be almost completely prevented with 10 times higher concentration of nifedipine $(200 \mu \mathrm{M})$ (Fig. 4b). Thus, in nodal cells, $\mathrm{I}_{\mathrm{Ca}}$ consists of two components. The larger component is insensitive to $10 \mu \mathrm{M}$ nifedipine, has the peak current at $-20 \mathrm{mV}$ (Fig. 4c), and therefore, is not $\mathrm{I}_{\mathrm{CaL}}$. In transitional AV cells, no inward current was observed in the presence of $0.3 \mu \mathrm{M}$ TTX and $20 \mu \mathrm{M}$ nifedipine (data not shown).

\section{Transcript expression}

Transcript expression of 42 genes encoding $\mathrm{Ca}^{2+}, \mathrm{K}^{+}$and $\mathrm{Na}^{+}$channels and the islet- 1 transcription factor were studied by real-time quantitative PCR (qPCR). mRNA levels were normalized to the expression of DnaJ (hsp40) subfamily A member 2 (dnaja2) whose transcript expression in different cardiac compartments is more stable than the expression of commonly used reference genes such as $\beta$-actin, glyceraldehyde phosphate dehydrogenase and ribosomal proteins (Vornanen et al. 2005; Hassinen et al. 2015). Since it was not possible to separate the AV muscle cleanly from the working myocardia, the narrow AV tissue ring was cut in two parts. $\mathrm{AV}$-atr and $\mathrm{AV}$-ven pieces are thought to include some atrial or ventricular myocardium in addition to the AV tissue, meaning that the mRNA expressions measured from them are likely to represent a mixture of expression profiles of actual AV tissue and working myocardium. 

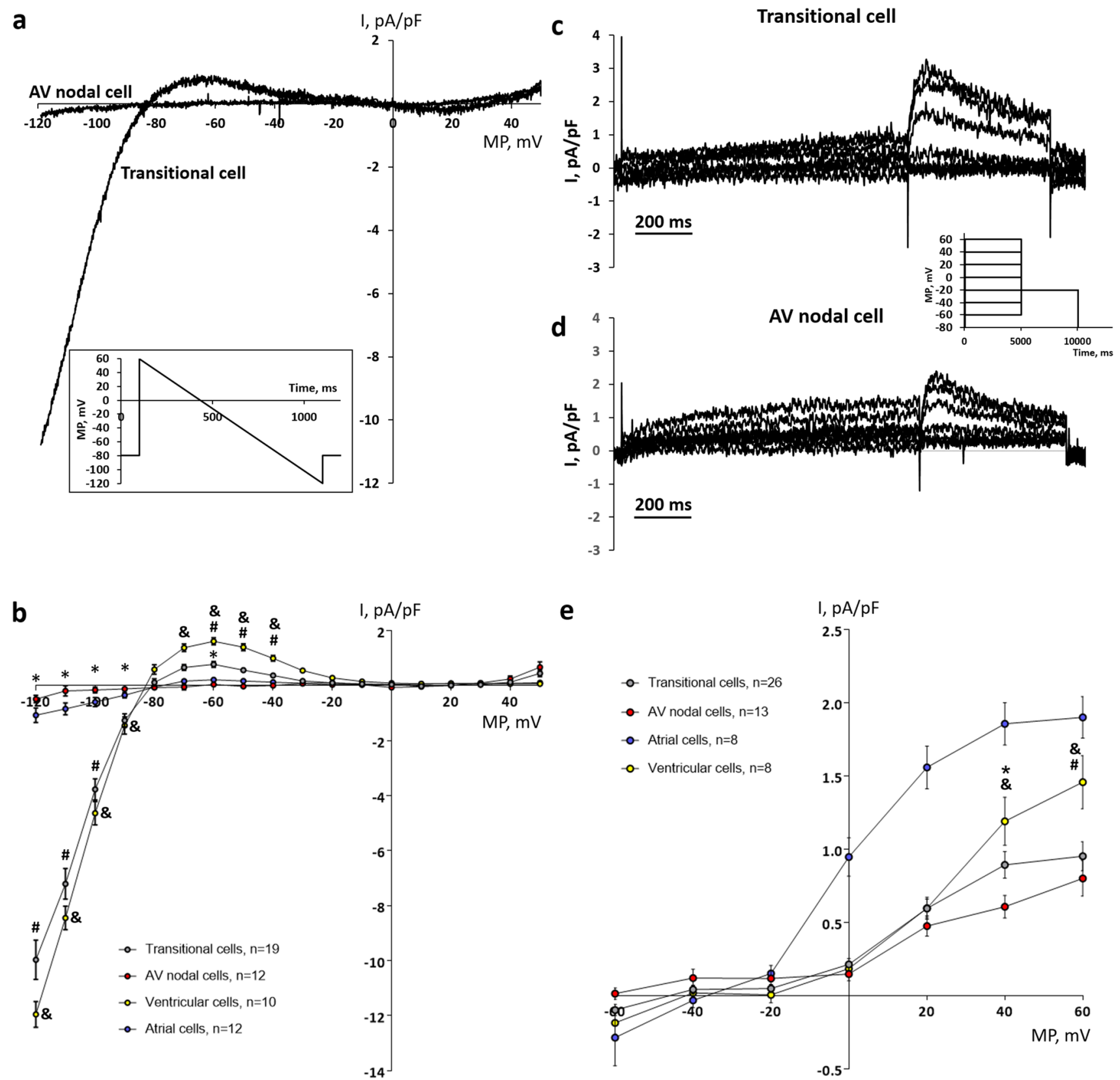

e

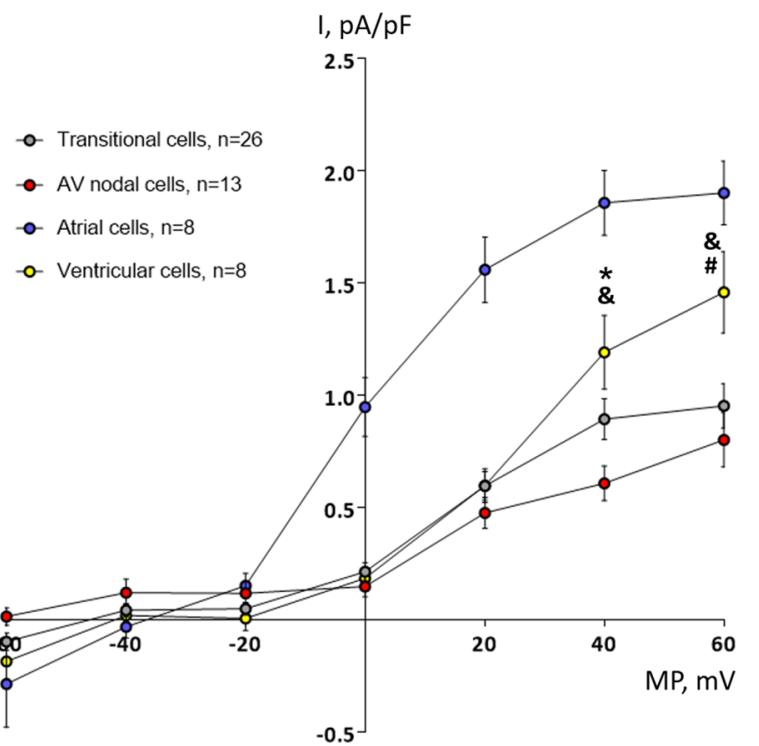

Fig. 2 Comparison of the main $\mathrm{K}^{+}$currents in $\mathrm{AV}$ canal, ventricle and atrium of the rainbow trout heart. a Original tracings of inward rectifier $\mathrm{K}^{+}$current $\left(I_{\mathrm{K} 1}\right)$ in a representative transitional cell and a typical AV nodal cell. The currents were elicited by a hyperpolarizing ramp (from +60 to $-120 \mathrm{mV}$ ) starting from the holding potential of $-80 \mathrm{mV}$ (inset). b $I-V$ curves of the $I_{\mathrm{K} 1}$ obtained after subtraction of the leakage current in AV nodal cells, transitional cells, atrial myocytes and ventricular myocytes. The results are means \pm SEM of current densities from 10 to 19 cells of 6 fish. c, d Original recordings of delayed rectifier $\mathrm{K}^{+}$current $I_{\mathrm{K}}$ in a representative transitional cell

\section{Islet-1}

Islet- 1 is a marker of pacemaker cells of the fish sinoatrial tissue (Tessadori et al. 2012; Stoyek et al. 2016).

(c) and an AV nodal cell (d). The currents were elicited by a double square-pulse depolarization from the holding potential of $-80 \mathrm{mV}$ (inset). The density of $I_{\mathrm{Kr}}$ was measured as a tail current at $-20 \mathrm{mV}$. (e) The mean $I-V$ curves of the tail $I_{\mathrm{K}}$ density in AV nodal cells, transitional cells, atrial myocytes and ventricular myocytes. The results are means \pm SEM from 8 to 26 cells of 6 fish. In (b, e) statistically significant differences $(p<0.05$, two-way ANOVA with Tukey's multiple comparisons) are indicated between AV nodal and transitional cells $(*)$, between transitional cells and ventricular myocytes (\#) and between ventricular myocytes and AV nodal cells (\&)

Consistent with this the expression of islet-1 was significantly higher in SAN than in any other part of the trout heart $(p<0.05)$ (Fig. 5, Table 2). However, mRNA expression of islet-1 was only $3-4 \%$ of the expression level of 

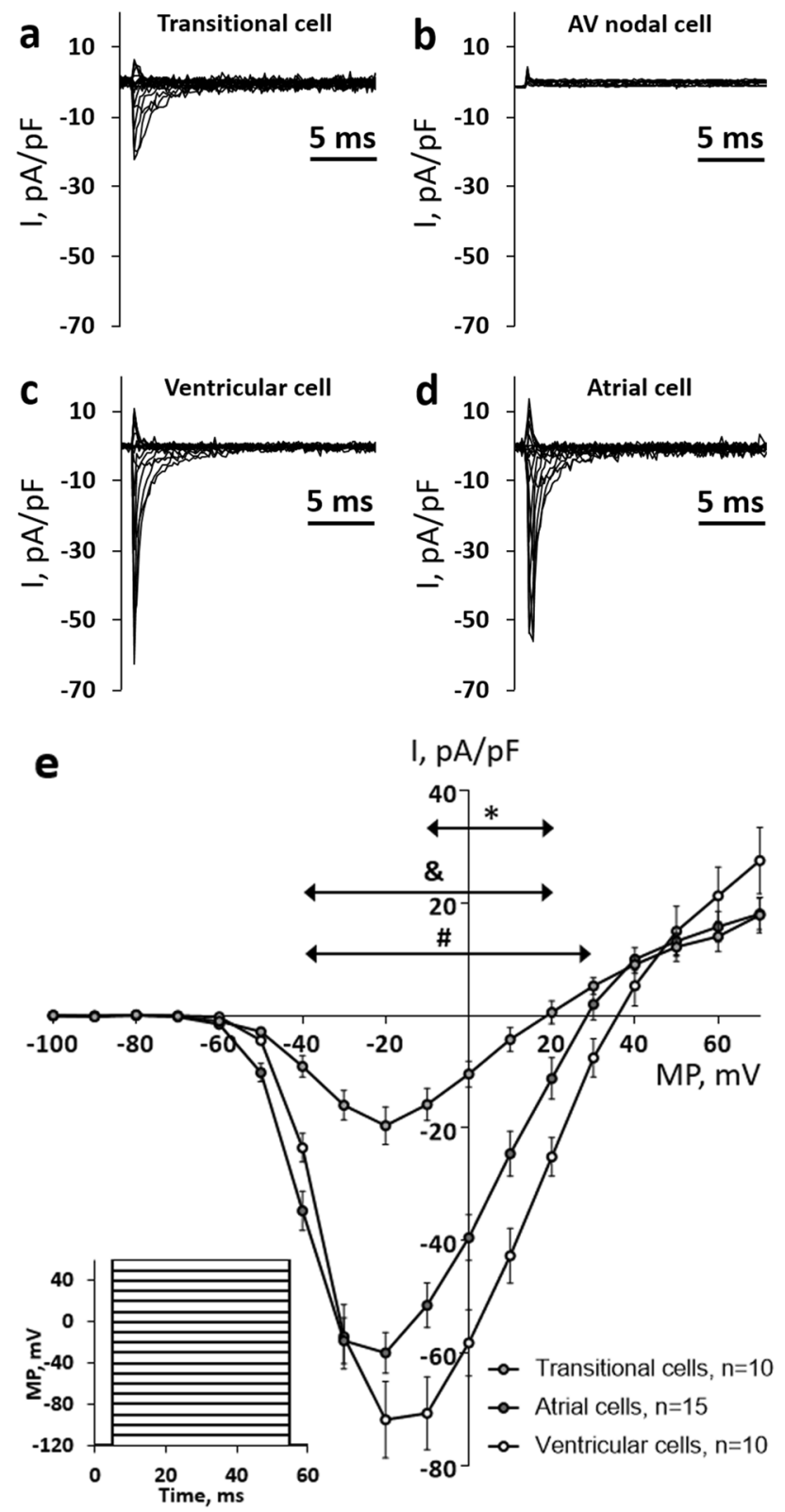

Fig. 3 Comparison of the fast sodium current $\left(I_{\mathrm{Na}}\right)$ of AV canal, ventricle and atrium of the rainbow trout heart. a-d Original recordings of $I_{\mathrm{Na}}$ in a representative transitional cell (a), a AV nodal cell (b), a working ventricular myocyte (c) and a working atrial myocyte (d). $\mathrm{I}_{\mathrm{Na}}$ was elicited by depolarization square-pulses from the holding potential of $-120 \mathrm{mV}$ (inset). (e) $I-V$ curves of $\mathrm{I}_{\mathrm{Na}}$ recorded in transitional cells, atrial myocytes and ventricular myocytes. The results are means \pm SEM of 10-15 cells from 5 fish. Statistically significant differences $(p<0.05$, two-way ANOVA with Tukey's multiple comparisons) are indicated between atrial and ventricular myocytes $(*)$, between transitional cells and atrial myocytes (\&), between transitional cells and ventricular myocytes (\#)

$\mathrm{KCNH}$ and $\mathrm{SCN}$ channels suggesting that pacemaker cells make up only a minor fraction of the SAN tissue. The expression of Islet-1 in the AV tissue did not differ from
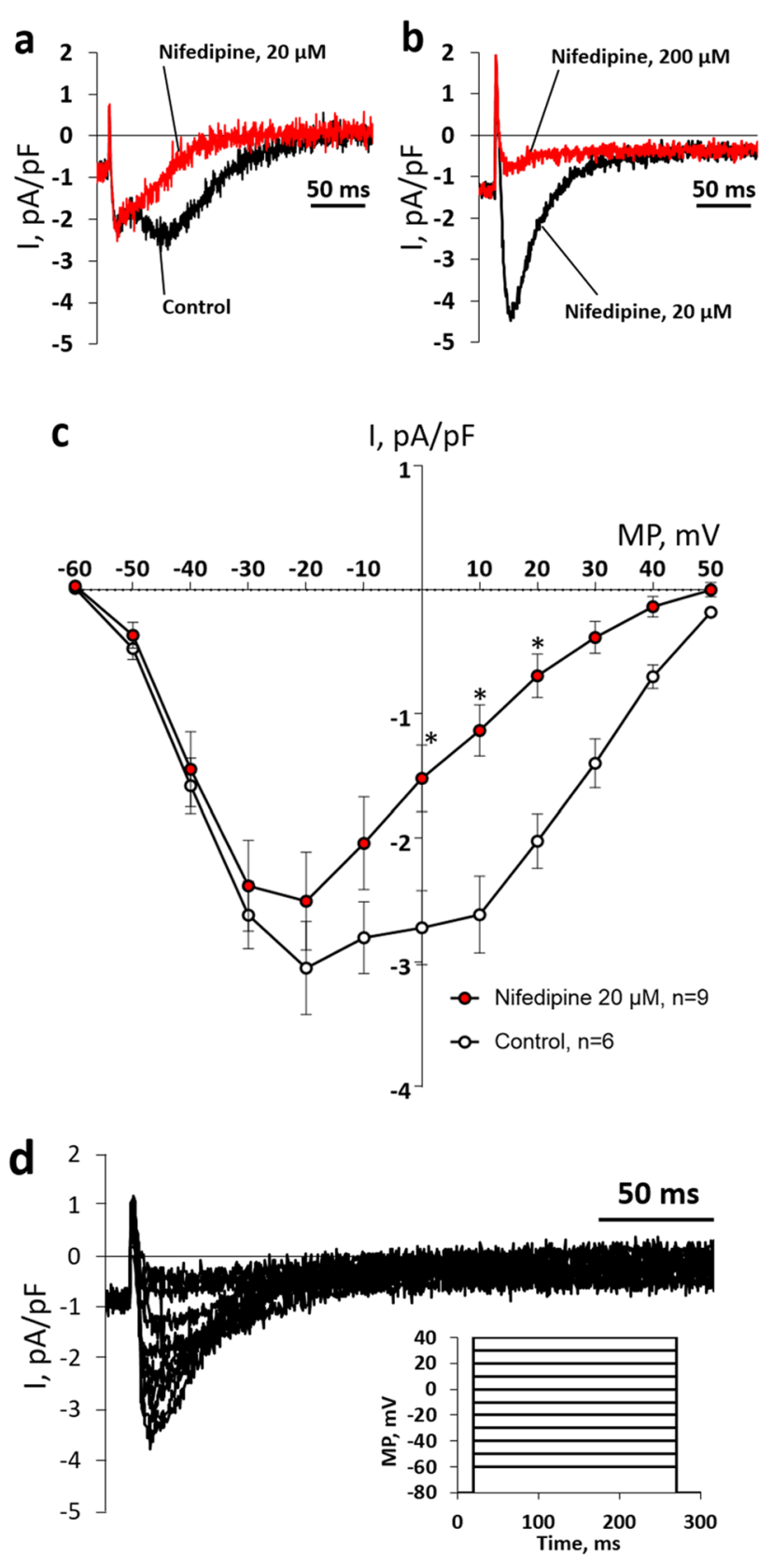

Fig. 4 Calcium currents $\left(I_{\mathrm{Ca}}\right)$ in nodal myocytes of rainbow trout $\mathrm{AV}$ canal. a, b Original recordings of $I_{\mathrm{Ca}}$ elicited by square-pulse depolarizations from the holding potential of $-80 \mathrm{mV}$ to $-10 \mathrm{mV}$ in two representative nodal myocytes. a Under control conditions, the current tracing has two inward current peaks, an early and a late one. Nifedipine $(20 \mu \mathrm{M})$ abolishes the late current peak. b A high concentration of nifedipine $(200 \mu \mathrm{M})$ almost eliminates the early peak of $I_{\mathrm{Ca}}$ which was resistant to $20 \mu \mathrm{M}$ nifedipine. c $I-V$ curves of $I_{\mathrm{Ca}}$ under control conditions and in the presence of $20 \mu \mathrm{M}$ nifedipine. The results are means \pm SEM of 6 and 9 cells from 5 fish for control and nifedipine experiments, respectively. The currents were elicited by square wave pulses from the holding potential of $-80 \mathrm{mV}$ (inset). An asterisk $(*)$ indicates a significant effect of nifedipine $(p<0.05$, twoway ANOVA with Tukey's multiple comparisons test). d An original current tracing of $20 \mu \mathrm{M}$ nifedipine-resistant component of $I_{\mathrm{Ca}}$ in a representative nodal AV myocyte 


\section{ISL1+ISL1L}

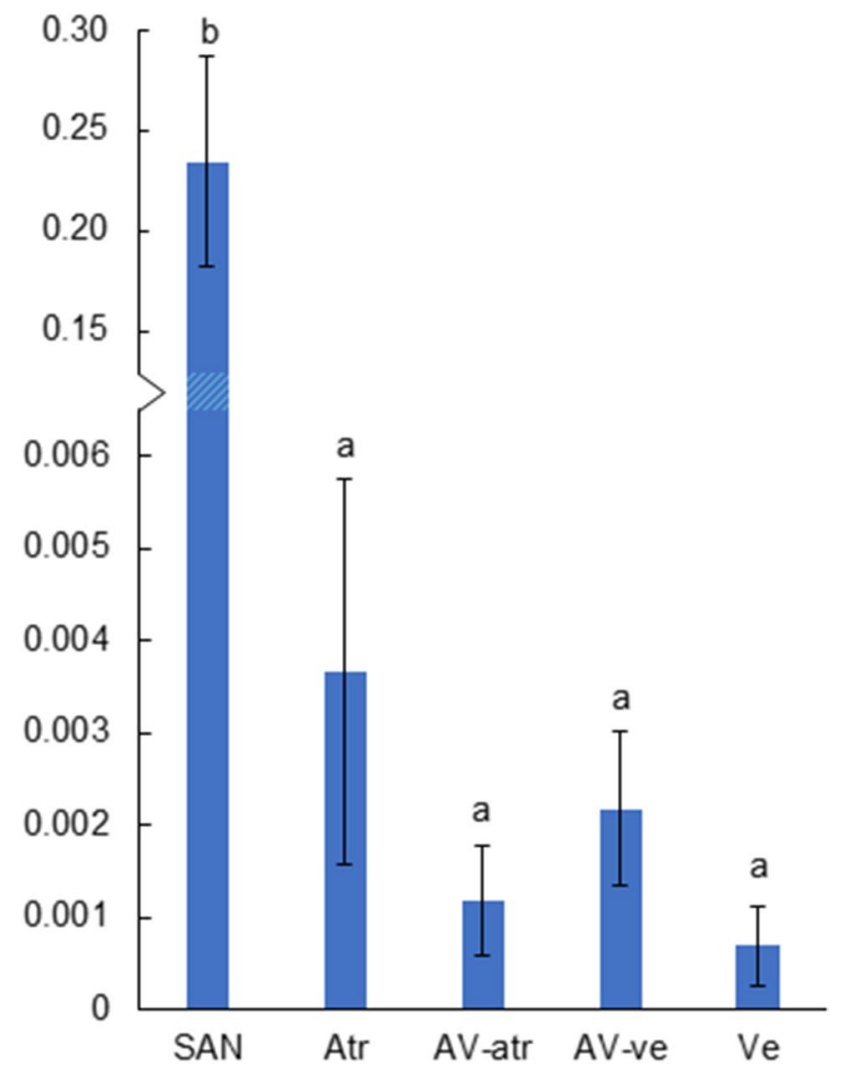

Fig. 5 The total transcript expression of Islet isoforms (ISL1 + ISL1L), transcription factor genes, in different parts of rainbow trout heart. Transcript abundances were normalized to the expression of the reference gene DnaJA2 $(n=5$, mean \pm S.E.M.). Note the break in $y$-axis. Statistically significant differences in gene expression between cardiac compartments are indicated by dissimilar letters $(p<0.05)$

those of atrium and ventricle $(p>0.05)$; the expression level of Islet-1 outside SAN was $1.5 \%$ or less.

\section{Inward rectifier $\mathrm{K}^{+}$channels}

The total Kir2 mRNA amount was highest in ventricle $(p<0.05)$ being $2,13,32$ and 44 times as high as in AVven, SAN, atrium and AV-atr, respectively (Fig. 6b). Notably, the total Kir2 mRNA abundance was lower in AV-ven than in ventricle, while it was similar in $\mathrm{AV}$-atr and atrium (Table 2). The isoform composition of Kir2 channels was markedly different between different cardiac compartments. In ventricle and AV-ven, Kir2.4 represented 96.6 \pm 0.9 and $95.4 \pm 0.6 \%$ of all Kir2 transcripts, respectively, while Kir2.4 was weakly expressed (2.0-5.1\%) in other cardiac compartments (Fig. 6c). Indeed, the amount of Kir2.4 mRNA in the ventricle was approximately 2-, 520-, 960- and 3300-fold higher $(p<0.05)$ than in $\mathrm{AV}$-ven, SAN, atrium and AV-atr, respectively (Fig. 6a). In SAN, atrium and AV-atr Kir2 isoform composition was more variable, but different Kir2.2 paralogs formed most (50.4-71.4\%) of the Kir2 channels in these tissues. The AV tissue is clearly a transition zone (caudal to cranial direction) in which Kir2 expression changes from very low to high and mainly from Kir2 to mainly Kir4 type.

\section{Delayed rectifier $\mathrm{K}^{+}$channels}

Expression of all known delayed rectifier $\mathrm{K}^{+}$channels encoding $\mathrm{KCNH} 2,-6$ and -7 isoforms in rainbow trout were studied (Fig. 7). The total KCNH mRNA level was higher in atrium and $\mathrm{AV}$-atr than in $\mathrm{AV}$-ven and ventricle $(p<0.05)$ (Fig. 7b). KCNH expression in SAN was equal to that of atrium, AV-atr and ventricle but higher than in AV-ven. $\mathrm{KCNH6a}$ was the most highly expressed $\mathrm{KCNH}$ isoform in all cardiac compartments representing $78.8-99.7 \%$ of all $\mathrm{KCNH}$ transcripts (Fig. 7c). Its expression was lower in AVven than in atrium and $\mathrm{AV}$-atr (Fig. 7a). KCNH7 paralogs (except to $\mathrm{KCNH} 7 \mathrm{bb}$ ) were more abundant in $\mathrm{SAN}, \mathrm{AV}$-atr and atrium than in AV-ven and ventricle $(p<0.05)$. KCN$\mathrm{H} 7 \mathrm{ab}$ represented $13.6-17.2 \%$ of all $\mathrm{KCNH}$ transcripts in atrium, AV-atr and SAN whereas its percentual value was negligible in $\mathrm{AV}$-ven and ventricle. Expression of $\mathrm{KCNH} 2$ paralogs (orthologs to the human erg) was very low in all cardiac compartments of the trout heart. In respect to $\mathrm{KCNH}$ channels, the AV tissue is a transitional zone (caudal to cranial direction) from high to low expression level and from the mixed $\mathrm{KCNH} 6 / \mathrm{KCNH} 7$ type to more homogenous KCNH6 type.

\section{$\mathrm{Na}^{+}$channels}

Expression of three Nav1.4 and three Nav1.5 encoding SCN paralogs (SCN4A/5LAa, -ba and -bb) were studied from atrium and ventricle (Fig. 8). Since the expressions of SCN4Aa and SCN5LAa were very low (0.003-0.03\% of all SCN transcripts) in these tissues, the study of other tissues was limited to the four most expressed $\mathrm{Na}^{+}$channel isoforms. Surprisingly, the total expression of SCN transcripts among all cardiac compartments was highest in the SAN $(p<0.05)$ (Fig. 8b). The total SCN mRNA amount was significantly higher in atrium than in ventricle, but even if the expression seemed to be lower in the $\mathrm{AV}$ area than in the atrial myocardium, the difference was not statistically significant either for AV-atr or AV-ven (Fig. 8b). However, if the data from $\mathrm{AV}$-atr and $\mathrm{AV}$-ven are combined, then atrial expression exceeds AV expression $(p<0.05)$. Although SCN4 paralogs formed most of the $\mathrm{Na}^{+}$channels transcripts in all cardiac compartments, there was some variation in the isoform composition between tissues (Fig. 8c). The relative amount of SCN4Abb was highest in SAN $(80.8 \pm 2.9 \%)$ 
Table 2 Fold changes of gene expression between different cardiac compartments

\begin{tabular}{|c|c|c|c|c|c|c|c|}
\hline & $\begin{array}{l}\text { Fold change } \\
\text { AV-atr/atr }\end{array}$ & $\begin{array}{l}\text { Fold change } \\
\mathrm{AV} \text {-ven/ven }\end{array}$ & $\begin{array}{l}\text { Fold change } \\
\text { Atr/ven }\end{array}$ & $\begin{array}{l}\text { Fold change } \\
\text { SV/atr }\end{array}$ & $\begin{array}{l}\text { Fold change } \\
\text { SV/ven }\end{array}$ & $\begin{array}{l}\text { Fold change } \\
\text { SV/AV-atr }\end{array}$ & $\begin{array}{l}\text { Fold change } \\
\text { SV/AV-ven }\end{array}$ \\
\hline SCN4Aba & $0.43 \pm 0.10 \downarrow$ & $0.34 \pm 0.04 \downarrow$ & $0.80 \pm 0.13$ & $0.86 \pm 0.16$ & $0.69 \pm 0.13$ & $1.99 \pm 0.36$ & $2.04 \pm 0.37$ \\
\hline SCN4Abb & $0.62 \pm 0.11$ & $2.80 \pm 0.55 \uparrow$ & $8.71 \pm 1.46 \uparrow$ & $7.86 \pm 1.52 \uparrow$ & $68.5 \pm 13.2 \uparrow$ & $12.70 \pm 2.46 \uparrow$ & $24.45 \pm 4.73 \uparrow$ \\
\hline SCN5LAba & $0.57 \pm 0.08$ & $0.31 \pm 0.08 \downarrow$ & $3.06 \pm 0.49 \uparrow$ & $0.74 \pm 0.15$ & $2.27 \pm 0.45$ & $1.30 \pm 0.26$ & $7.37 \pm 1.46 \uparrow$ \\
\hline SCN5LAbb & $0.74 \pm 0.12$ & $0.86 \pm 0.09$ & $2.33 \pm 0.45 \uparrow$ & $1.15 \pm 0.23$ & $2.68 \pm 0.55 \uparrow$ & $1.56 \pm 0.32$ & $3.12 \pm 0.63 \uparrow$ \\
\hline $\mathrm{SCN}$ tot & $0.57 \pm 0.06$ & $0.58 \pm 0.07$ & $2.13 \pm 0.27 \uparrow$ & $3.13 \pm 0.59 \uparrow$ & $6.66 \pm 1.25 \uparrow$ & $5.45 \pm 1.02 \uparrow$ & $11.56 \pm 2.17 \uparrow$ \\
\hline Kir2.1a & $0.58 \pm 0.07$ & $1.17 \pm 0.18$ & $0.66 \pm 0.09$ & $1.49 \pm 0.19$ & $0.98 \pm 0.12$ & $2.55 \pm 0.32 \uparrow$ & $0.84 \pm 0.11$ \\
\hline Kir2.1b & $1.14 \pm 0.36$ & $1.41 \pm 0.34$ & $0.70 \pm 0.22$ & $2.98 \pm 0.85$ & $2.09 \pm 0.59$ & $2.61 \pm 0.74$ & $1.48 \pm 0.42$ \\
\hline Kir2.2a & $1.26 \pm 0.21$ & $0.32 \pm 0.03$ & $0.37 \pm 0.02$ & $4.34 \pm 1.17$ & $1.60 \pm 0.43$ & $3.45 \pm 0.93$ & $4.97 \pm 1.34$ \\
\hline Kir $2.2 b$ & $0.68 \pm 0.38$ & $0.38 \pm 0.18$ & $1.42 \pm 0.87$ & $2.49 \pm 0.45$ & $3.54 \pm 0.63 \uparrow$ & $3.67 \pm 0.66 \uparrow$ & $9.42 \pm 1.69 \uparrow$ \\
\hline Kir2.4 & $0.29 \pm 0.23$ & $0.55 \pm 0.07 \downarrow$ & $0.0010 \pm 0.0007 \downarrow$ & $1.85 \pm 0.48$ & $0.00 \pm 0.00 \downarrow$ & $6.38 \pm 1.66$ & $0.004 \pm 0.001 \downarrow$ \\
\hline Kir2 tot & $0.71 \pm 0.22$ & $0.55 \pm 0.07 \downarrow$ & $0.03 \pm 0.01 \downarrow$ & $2.37 \pm 0.32$ & $0.07 \pm 0.01 \downarrow$ & $3.32 \pm 0.45 \uparrow$ & $0.14 \pm 0.02 \downarrow$ \\
\hline $\mathrm{KCNH} 2 \mathrm{aa}$ & $1.05 \pm 0.31$ & $3.60 \pm 0.81$ & $1.89 \pm 0.46$ & $6.31 \pm 1.30 \uparrow$ & $11.94 \pm 2.47 \uparrow$ & $6.00 \pm 1.24 \uparrow$ & $3.32 \pm 0.69 \uparrow$ \\
\hline $\mathrm{KCNH} 2 \mathrm{ab}$ & $1.68 \pm 0.73$ & $1.16 \pm 0.29$ & $0.76 \pm 0.31$ & $1.41 \pm 0.45$ & $1.06 \pm 0.34$ & $0.84 \pm 0.27$ & $0.92 \pm 0.29$ \\
\hline $\mathrm{KCNH} 2 \mathrm{ba}$ & $0.93 \pm 0.15$ & $2.13 \pm 0.41$ & $4.01 \pm 0.51$ & $2.33 \pm 0.36 \uparrow$ & $9.35 \pm 1.46 \uparrow$ & $2.50 \pm 0.39 \uparrow$ & $4.39 \pm 0.69 \uparrow$ \\
\hline $\mathrm{KCNH} 2 \mathrm{bb}$ & $0.76 \pm 0.23$ & $1.13 \pm 0.21$ & $3.38 \pm 0.79$ & $2.43 \pm 0.35 \uparrow$ & $8.21 \pm 1.19 \uparrow$ & $3.18 \pm 0.46 \uparrow$ & $7.25 \pm 1.05 \uparrow$ \\
\hline KCNH6a & $0.94 \pm 0.10$ & $0.62 \pm 0.08$ & $1.78 \pm 0.25$ & $0.76 \pm 0.12$ & $1.34 \pm 0.21$ & $0.81 \pm 0.13$ & $2.16 \pm 0.35$ \\
\hline KCNH6b & $1.29 \pm 0.34$ & $1.29 \pm 0.18$ & $0.96 \pm 0.29$ & $0.58 \pm 0.18$ & $0.56 \pm 0.17$ & $0.45 \pm 0.14$ & $0.43 \pm 0.14$ \\
\hline KCNH7aa & $0.91 \pm 0.31$ & $4.68 \pm 1.41$ & $470.1 \pm 119.5 \uparrow$ & $0.45 \pm 0.09$ & $212.3 \pm 44.2 \uparrow$ & $0.50 \pm 0.10$ & $45.35 \pm 9.43 \uparrow$ \\
\hline $\mathrm{KCNH} 7 \mathrm{ab}$ & $0.91 \pm 0.05$ & $48.7 \pm 19.9$ & $1584.3 \pm 247.4 \uparrow$ & $0.97 \pm 0.16$ & $1541.4 \pm 249.4 \uparrow$ & $1.06 \pm 0.17$ & $31.65 \pm 5.12 \uparrow$ \\
\hline $\mathrm{KCNH} 7 \mathrm{ba}$ & $0.73 \pm 0.09$ & $3.22 \pm 0.68 \uparrow$ & $83.85 \pm 17.84 \uparrow$ & $0.36 \pm 0.06$ & $29.98 \pm 5.03 \uparrow$ & $0.49 \pm 0.08 \downarrow$ & $9.31 \pm 1.56 \uparrow$ \\
\hline $\mathrm{KCNH} 7 \mathrm{bb}$ & $1.02 \pm 0.25$ & $2.52 \pm 0.66$ & $2.73 \pm 0.90$ & $4.76 \pm 0.18 \uparrow$ & $13.00 \pm 0.49 \uparrow$ & $4.66 \pm 0.18 \uparrow$ & $5.16 \pm 0.19 \uparrow$ \\
\hline $\mathrm{KCNH}$ tot & $0.93 \pm 0.08$ & $0.63 \pm 0.09$ & $2.19 \pm 0.29 \uparrow$ & $0.77 \pm 0.12$ & $1.69 \pm 0.26$ & $0.83 \pm 0.13$ & $2.67 \pm 0.41 \uparrow$ \\
\hline HCN1a & $1.29 \pm 0.64$ & $4.34 \pm 1.23$ & $0.64 \pm 0.26$ & $63.9 \pm 9.32 \uparrow$ & $41.08 \pm 5.99 \uparrow$ & $49.49 \pm 7.21 \uparrow$ & $9.47 \pm 1.38 \uparrow$ \\
\hline HCN1b & $1.01 \pm 0.15$ & $2.43 \pm 0.55$ & $11.12 \pm 1.28 \uparrow$ & $1.09 \pm 0.23$ & $12.15 \pm 2.60 \uparrow$ & $1.09 \pm 0.23$ & $4.99 \pm 1.07 \uparrow$ \\
\hline HCN2aa & $2.03 \pm 0.28$ & $0.35 \pm 0.07 \downarrow$ & $0.41 \pm 0.08 \downarrow$ & $4.47 \pm 0.82 \uparrow$ & $1.82 \pm 0.33$ & $2.21 \pm 0.40$ & $5.24 \pm 0.96 \uparrow$ \\
\hline $\mathrm{HCN} 2 \mathrm{ab}$ & $1.91 \pm 0.48$ & $1.80 \pm 0.26$ & $2.07 \pm 0.53$ & $16.6 \pm 1.39 \uparrow$ & $34.22 \pm 2.86 \uparrow$ & $8.67 \pm 0.73 \uparrow$ & $19.0 \pm 1.59 \uparrow$ \\
\hline $\mathrm{HCN} 2 \mathrm{ba}$ & $0.47 \pm 0.14$ & $4.71 \pm 1.21 \uparrow$ & $1.23 \pm 0.57$ & $36.1 \pm 4.40 \uparrow$ & $44.27 \pm 5.40 \uparrow$ & $77.22 \pm 9.41 \uparrow$ & $9.40 \pm 1.15 \uparrow$ \\
\hline $\mathrm{HCN} 2 \mathrm{bb}$ & $1.16 \pm 0.12$ & $0.63 \pm 0.05 \downarrow$ & $1.00 \pm 0.09$ & $4.16 \pm 0.22 \uparrow$ & $4.17 \pm 0.22 \uparrow$ & $3.58 \pm 0.19 \uparrow$ & $6.63 \pm 0.35 \uparrow$ \\
\hline $\mathrm{HCN} 3 \mathrm{a}$ & $4.29 \pm 0.96 \uparrow$ & $25.3 \pm 5.04 \uparrow$ & $7.14 \pm 1.45 \uparrow$ & $59.9 \pm 19.58 \uparrow$ & $427.5 \pm 139.9 \uparrow$ & $13.96 \pm 4.57 \uparrow$ & $16.92 \pm 5.53 \uparrow$ \\
\hline $\mathrm{HCN} 3 \mathrm{~b}$ & $9.78 \pm 7.10$ & $2.01 \pm 0.75$ & $0.98 \pm 0.44$ & $64.0 \pm 4.80 \uparrow$ & $78.60 \pm 5.90 \uparrow$ & $6.54 \pm 0.49 \uparrow$ & $31.22 \pm 2.34 \uparrow$ \\
\hline $\mathrm{HCN} 4 \mathrm{a}$ & $1.06 \pm 0.11$ & $6.80 \pm 1.26 \uparrow$ & $18.40 \pm 1.59 \uparrow$ & $3.49 \pm 0.66 \uparrow$ & $64.19 \pm 12.09 \uparrow$ & $3.29 \pm 0.62 \uparrow$ & $9.44 \pm 1.78 \uparrow$ \\
\hline HCN4ba & $0.63 \pm 0.14$ & $2.59 \pm 0.80$ & $1.27 \pm 0.43$ & $9.06 \pm 2.00 \uparrow$ & $11.55 \pm 2.55 \uparrow$ & $14.32 \pm 3.16 \uparrow$ & $4.46 \pm 0.99 \uparrow$ \\
\hline $\mathrm{HCN} 4 \mathrm{bb}$ & $0.64 \pm 0.21$ & $0.96 \pm 0.18$ & $0.92 \pm 0.47$ & $19.9 \pm 1.86 \uparrow$ & $18.36 \pm 1.72 \uparrow$ & $24.96 \pm 2.34 \uparrow$ & $19.17 \pm 1.79 \uparrow$ \\
\hline $\mathrm{HCN}$ tot & $1.09 \pm 0.12$ & $3.73 \pm 0.56 \uparrow$ & $6.87 \pm 0.64 \uparrow$ & $5.07 \pm 0.84 \uparrow$ & $34.85 \pm 5.79 \uparrow$ & $4.65 \pm 0.77 \uparrow$ & $9.34 \pm 1.55 \uparrow$ \\
\hline CACNA1C & $0.85 \pm 0.13$ & $0.99 \pm 0.30$ & $0.63 \pm 0.14$ & $1.65 \pm 0.38$ & $1.04 \pm 0.24$ & $1.94 \pm 0.45$ & $1.05 \pm 0.24$ \\
\hline CACNA1Daa & $1.18 \pm 0.29$ & $2.22 \pm 0.24$ & $0.62 \pm 0.17$ & $10.7 \pm 1.28 \uparrow$ & $6.63 \pm 0.79 \uparrow$ & $9.03 \pm 1.08 \uparrow$ & $2.99 \pm 0.36 \uparrow$ \\
\hline CACNA1Dab & $2.20 \pm 0.70$ & $0.88 \pm 0.27$ & $0.39 \pm 0.13$ & $5.45 \pm 0.51 \uparrow$ & $2.15 \pm 0.20$ & $2.47 \pm 0.23$ & $2.44 \pm 0.22$ \\
\hline CACNA1Dba & $0.82 \pm 0.22$ & $2.39 \pm 0.70$ & $1.18 \pm 0.18$ & $77.3 \pm 6.44 \uparrow$ & $91.56 \pm 7.63 \uparrow$ & $94.76 \pm 7.90 \uparrow$ & $38.35 \pm 3.20 \uparrow$ \\
\hline CACNA1Dbb & $1.35 \pm 0.20$ & $1.61 \pm 0.30$ & $1.11 \pm 0.13$ & $2.62 \pm 0.29 \uparrow$ & $2.91 \pm 0.32 \uparrow$ & $1.94 \pm 0.21$ & $1.81 \pm 0.20$ \\
\hline CACNA1Ga & $3.25 \pm 0.95 \uparrow$ & $4.04 \pm 1.25 \uparrow$ & $0.33 \pm 0.12$ & $7.35 \pm 1.16 \uparrow$ & $2.44 \pm 0.39$ & $2.26 \pm 0.36$ & $0.60 \pm 0.10$ \\
\hline CACNA1Gb & $1.03 \pm 0.58$ & $2.87 \pm 0.61$ & $1.50 \pm 0.66$ & $11.8 \pm 2.14 \uparrow$ & $17.65 \pm 3.22 \uparrow$ & $9.11 \pm 1.66 \uparrow$ & $6.15 \pm 1.12 \uparrow$ \\
\hline CACNA1Ha & $1.61 \pm 0.48$ & $2.06 \pm 0.29$ & $0.97 \pm 0.22$ & $4.19 \pm 0.27 \uparrow$ & $4.08 \pm 0.26 \uparrow$ & $2.61 \pm 0.17 \uparrow$ & $1.97 \pm 0.13$ \\
\hline CACNA1Hb & $1.02 \pm 0.22$ & $0.87 \pm 0.20$ & $0.57 \pm 0.10$ & $2.02 \pm 0.17$ & $1.14 \pm 0.09$ & $1.99 \pm 0.17$ & $1.31 \pm 0.11$ \\
\hline CACNA1Ia & $1.32 \pm 0.72$ & $2.09 \pm 0.88$ & $1.15 \pm 0.50$ & $2.47 \pm 0.18$ & $2.84 \pm 0.21$ & $1.86 \pm 0.14$ & $1.36 \pm 0.10$ \\
\hline CACNA1Ib & $1.38 \pm 0.76$ & $2.47 \pm 0.97$ & $1.18 \pm 0.74$ & $0.32 \pm 0.12$ & $0.38 \pm 0.14$ & $0.23 \pm 0.09$ & $0.15 \pm 0.06$ \\
\hline CACNA1 tot & $1.13 \pm 0.17$ & $1.53 \pm 0.39$ & $0.59 \pm 0.12$ & $2.67 \pm 0.38 \uparrow$ & $1.57 \pm 0.22$ & $2.38 \pm 0.33 \uparrow$ & $1.03 \pm 0.14$ \\
\hline ISL1 + ISL1L & $0.33 \pm 0.16$ & $3.14 \pm 1.19$ & $5.28 \pm 3.03$ & $64.0 \pm 14.37 \uparrow$ & $338.0 \pm 75.9 \uparrow$ & $196.2 \pm 44.0 \uparrow$ & $107.5 \pm 24.1 \uparrow$ \\
\hline
\end{tabular}

Values are mean \pm SEM

$(\uparrow)$ indicates statistically significant upregulation and $(\downarrow)$ indicates significant downregulation of the mRNA level 


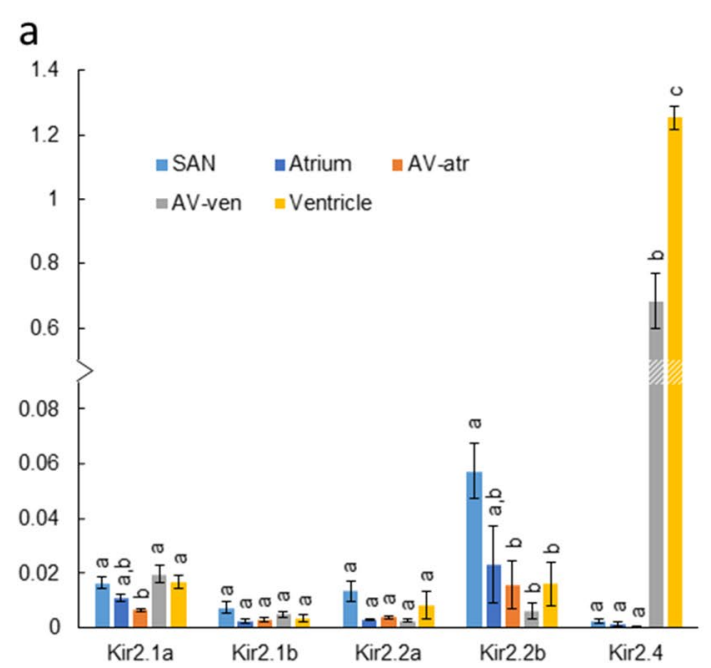

b

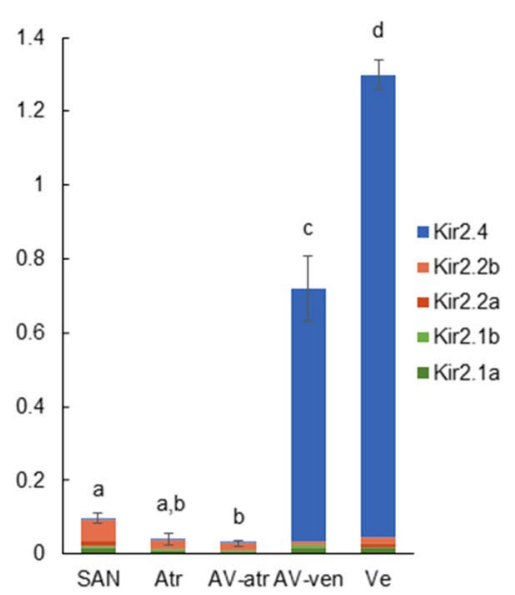

C

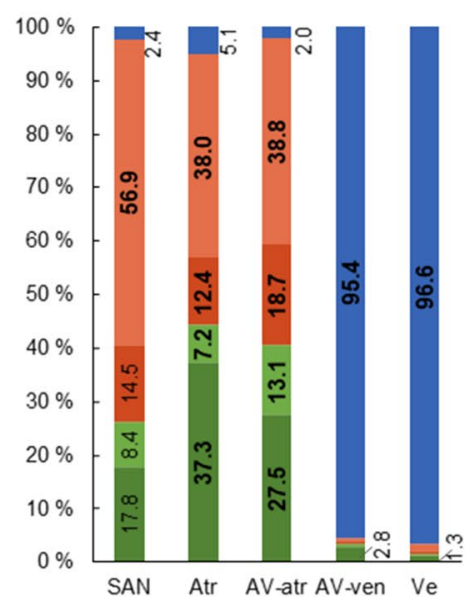

Fig. 6 Transcript abundance of Kir2.1, -2.2 and -2.4 isoforms in cardiac compartments. Since Kir2.1aa and -ab share high sequence similarity, their mRNAs were measured by primers identical for both isoforms. Transcripts of Kir2.2aa and -ab as well as Kir2.2ba and -bb were measured similarly. a Transcript abundances of Kir2 genes normalized to the expression of reference gene DnaJA2 $(n=5$, mean \pm S.E.M.). Statistically significant differences in the expression of each gene between cardiac compartments are indicated by dissimilar letters $(p<0.05)$. b Stacked bars represent the total Kir2 transcript abundance (mean \pm S.E.M.) in different cardiac compartments. $\mathbf{c}$ Percentage of each Kir2 isoform from total Kir2 transcript abundance. The percentage value of the most expressed isoform is represented as bold (if two or more isoforms are statistically equally expressed, both/ all of them are marked as bold)

a
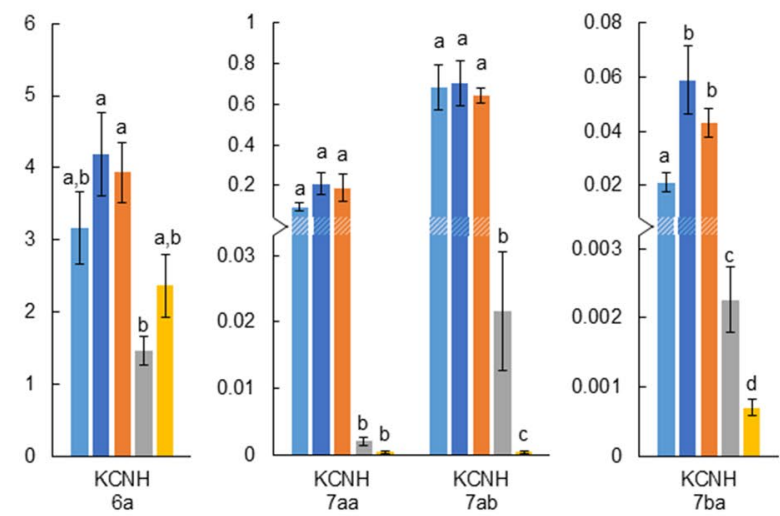

$2 a a$

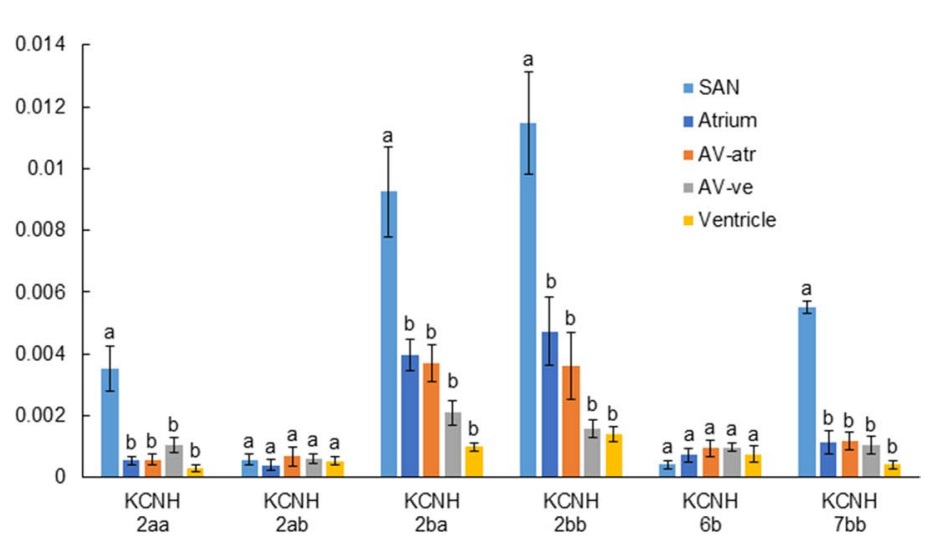

$=\mathrm{KCNH} 7 \mathrm{bb}$

$=\mathrm{KCNH} 7 \mathrm{ba}$

$\because \mathrm{KCNH} 7 \mathrm{ab}$

- KCNH7aa

$₫ \mathrm{KCNH} 6 \mathrm{~b}$

$=\mathrm{KCNH} 6 \mathrm{a}$

$=\mathrm{KCNH} 2 \mathrm{bb}$

$\because \mathrm{KCNH} 2 \mathrm{ba}$

$\because \mathrm{KCNH} 2 \mathrm{ab}$

$=\mathrm{KCNH} 2 \mathrm{aa}$

C

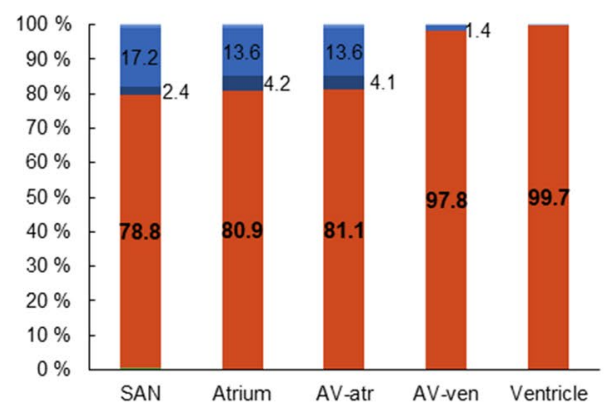

isoforms (mean \pm S.E.M.). c Relative proportion (\%) of each $\mathrm{KCNH}$ isoform from all $\mathrm{KCNH}$ transcript expression shows that KCNH6a is the main isoform whereas $\mathrm{KCNH} 2$ isoforms are negligible in all cardiac chambers, and relative proportion of $\mathrm{KCNH} 7 \mathrm{ab}$ is higher in $\mathrm{SAN}, \mathrm{AV}$-atr and atrium than in $\mathrm{AV}$-ven and ventricle 

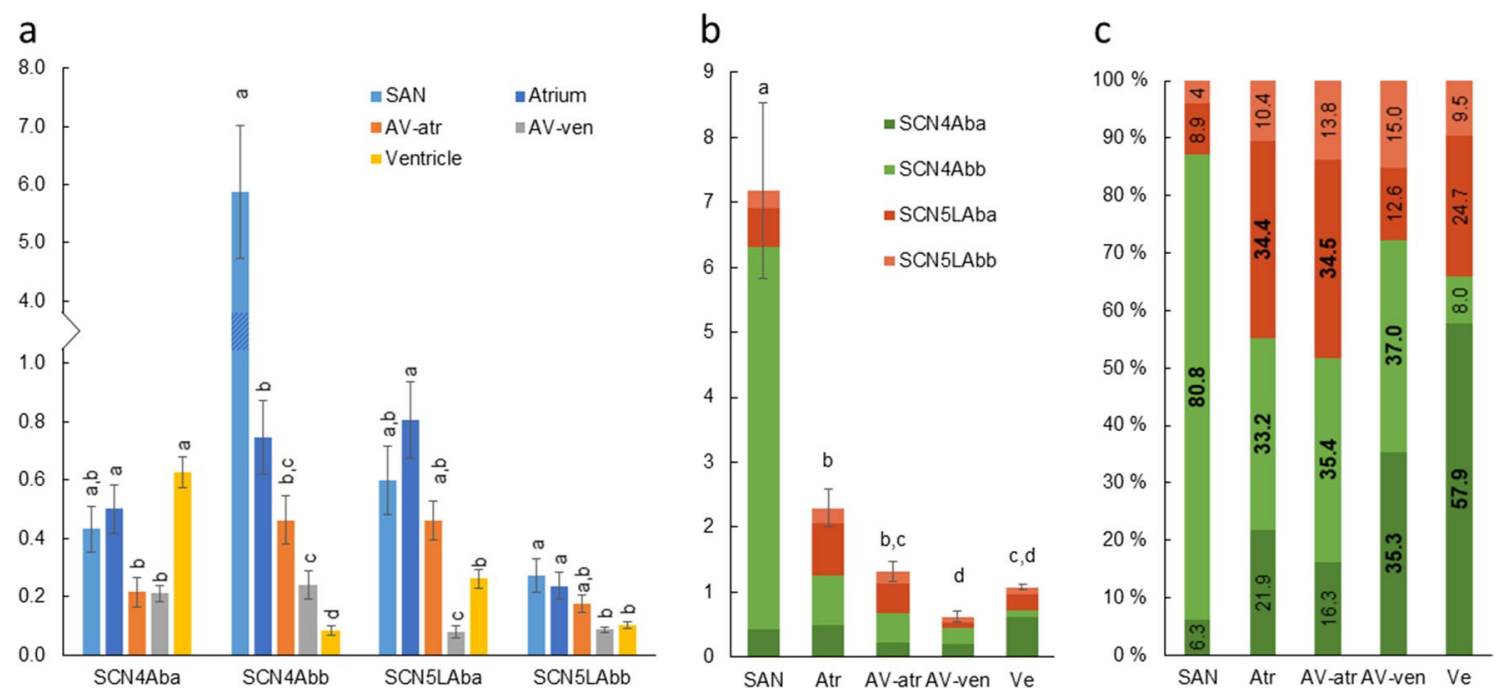

Fig. 8 Transcript expression of SCN genes encoding Nav1.4 and Nav1.5 channels. a Transcript abundances of SCN genes normalized to the expression of reference gene DnaJA2 $(n=5$, mean \pm S.E.M.). Statistically significant differences in the expression of each gene between cardiac compartments are indicated by dissimilar letters $(p<0.05)$. b Total expression of SCN4A and -5LA isoforms in each cardiac compartment (mean \pm S.E.M.) shows that SCN expression

and lowest in ventricle $(8.0 \pm 1.5 \%)$ (Fig. 8a). In atrium and $\mathrm{AV}$-atr, SCN4Abb and -5LAba were the most expressed isoforms. In ventricle, SCN4Aba was the dominating isoform $(57.9 \pm 3.3 \%)$, whereas SCN4Aba $(35.3 \pm 4.0 \%)$ and SCN4Abb $(37.0 \pm 4.7 \%)$ together dominated in AV-ven. In summary, the expression level of $\mathrm{Na}^{+}$channels appears to reach a minimum in the $\mathrm{AV}$ tissue $(\mathrm{AV}$-ven).

\section{$\mathrm{Ca}^{2+}$ channels}

Transcript expression of L- (CACNA1C and -D) and T-type (CACNA1G, - $\mathrm{H}$ and -I) $\mathrm{Ca}^{2+}$ channels was studied from all five compartments of the trout heart (Fig. 9). The total amount of $\mathrm{Ca}^{2+}$ channel transcripts was clearly higher in SAN and $\mathrm{AV}$-ven than other cardiac tissues with the exception of the ventricle $(p<0.05)$ (Fig. 9b). No differences existed in the total $\mathrm{Ca}^{2+}$ channel transcripts between atrium, $\mathrm{AV}$-atr and ventricle. Although CACNA1C (Cav1.2) and CACNA1Ga (Cav3.1a) were the most expressed isoforms in all cardiac tissues, there were some notable differences in isoform composition between cardiac compartments (Fig. 9a). The total amount of T-type $\mathrm{Ca}^{2+}$ channel mRNAs was higher in $\mathrm{AV}$-ven than in ventricle, atrium and AV-atr $(p<0.05)$. CACNA1Ga transcripts were more abundant in the $\mathrm{AV}$-atr and $\mathrm{AV}$-ven than in the corresponding working myocardia. Notably, expression levels of in SAN is higher than in other cardiac parts. c Relative proportion of each SCN isoform in cardiac compartments. SCN4Aba is more abundant in SAN and less abundant in ventricle than in other cardiac parts. The percentage value of the most expressed isoform is represented as bold (if two or more isoforms are statistically equally expressed, both/all of them are marked as bold)

CACNA1Daa, -Dba, -Ha and -Gb were significantly higher in SAN than in all other cardiac compartments. In brief, the AV tissue is characterized by abundant expression of the kinetically fast $\mathrm{T}$-type $\mathrm{Ca}^{2+}$ channels.

\section{Pacemaker channels}

Expression levels of all known rainbow trout $\mathrm{HCN}$ isoforms (HCN1a and -b, HCN2aa, -ab, -ba and -bb, HCN3a and -b, and $\mathrm{HCN} 4 \mathrm{a}$, -ba and -bb) were measured from different parts of the heart. HCN4a, $-1 \mathrm{a}$ and $-1 \mathrm{~b}$ were the most expressed isoforms (Fig. 10). The most striking finding in HCN transcript expression was the higher abundance of HCN channels in SAN than in any other part of the heart (Fig. 10a). Total HCN transcript abundance decreased from caudal to cranial direction in the order: $\mathrm{SAN}>>$ atrium $=\mathrm{AV}$-atr $>\mathrm{AV}$-ven $>$ ventricle, as $\mathrm{HCN}$ transcripts in SAN were $5.1 \pm 0.8-, 4.7 \pm 0.8-, 9.3 \pm 1.6-$ and $34.8 \pm 5.8$-fold compared to atrium, AV-atr, AV-ven and ventricle, respectively (Fig. 10b). With the exception of HCN1b and $\mathrm{HCN} 2 \mathrm{aa}$, all $\mathrm{HCN}$ isoforms were significantly more expressed in SAN than in other parts of the heart (Fig. 10a). No differences existed in HCN composition between AV-atr and atrium $(p>0.05)$. In contrast, HCN1a, $-4 a,-3 a$ and $-2 b a$ as well as the total amount of $\mathrm{HCN}$ transcripts were higher in $\mathrm{AV}$-ven than ventricle. 

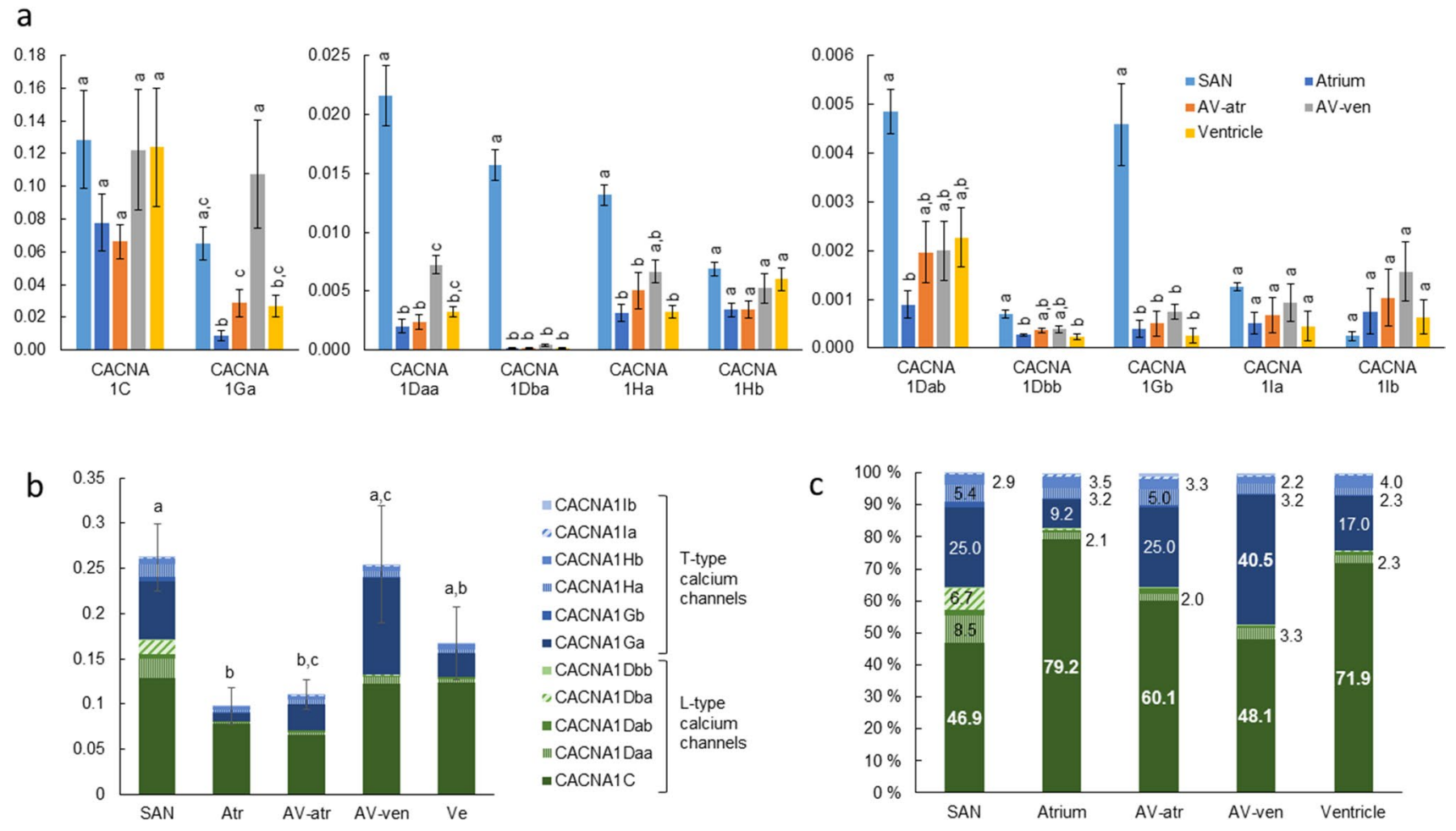

c

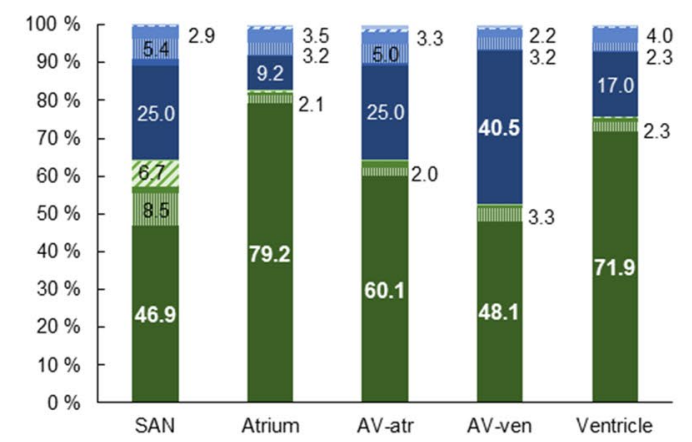

Fig. 9 Transcript expression of L- and T-type $\mathrm{Ca}^{2+}$ channel encoding genes. a Transcript abundance of different CACNA1 genes varies thus they are represented in diagrams with different $y$-axis scales. $\mathbf{b}$

\section{Discussion}

To our knowledge, this is the first study to investigate ion currents and ion channel expression in fish AV tissue. The trout AV canal forms a clear transition zone between the atrium and the ventricle in respect to ion channel composition and ion current densities. Yet, the AV nodal tissue has a typical electrophysiological phenotype that differs from those of SAN, atrium, and ventricle both in terms of ion current densities and expression of ion channel transcripts. In the rainbow trout $\mathrm{AV}$ canal, two types of $\mathrm{AV}$ cardiomyocytes, transitional cells and nodal cells, were distinguished: the transitional cells are intermediate between nodal cells and working atrial/ventricular myocytes, whereas the nodal cells are more similar to the SAN cells, because they have less negative $V_{\text {rest }}$, small $\mathrm{I}_{\mathrm{K} 1}$ and no $I_{\mathrm{Na}}$. To which extent atrial and ventricular myocytes are an integral part of the fish AV canal, or represent contamination by actual atrial/ ventricular tissue, remains to be elaborated by more detailed studies.

\section{Histology of the trout AV tissue}

The histological structure of the AV region is preserved in adult teleost species and is characterized by a compact
Expression of CACNA1 genes are represented as stacked bars to represent their total expression in each cardiac compartment. c Relative proportion $(\%)$ of each CACNA1 gene myocardium surrounded by the connective tissue (McWilliam 1885; Santer and Cobb 1972; Sedmera et al. 2003; Icardo and Colvee 2011; Stoyek et al. 2016). However, some variation in the amount of connective tissue and vascularization is observed between fish species (Icardo and Colvee 2011). In the heart of rainbow trout (and other teleosts), the $\mathrm{AV}$ region is composed of a myocardial ring or canal that is continuous with atrial and ventricular myocardia and laterally protected by robust connective tissue layers (Icardo and Colvee 2011). This arrangement of tissues is functionally relevant - to delay AP conduction - if atrial and ventricular myocytes are not in direct contact in any area of the canal. Therefore, we must assume that there is a zone composed exclusively of AV nodal myocytes that functionally separates atrial and ventricular myocardia. As the sole electrophysiological link between the atrium and the ventricle, the AV canal affects the function of the heart with its special structural and electrophysiological properties in normal physiological conditions and under environmental stresses. In particular, the small contact area between AV-ven and the ventricle proper is a potential site for AV block during acute heat stress. When a small cell/tissue mass (AV-ven) meets a much larger cell/tissue mass (ventricle), there is unfavorable ratio between depolarizing (source) current of active AV cells and repolarizing (sink) current of resting ventricular 

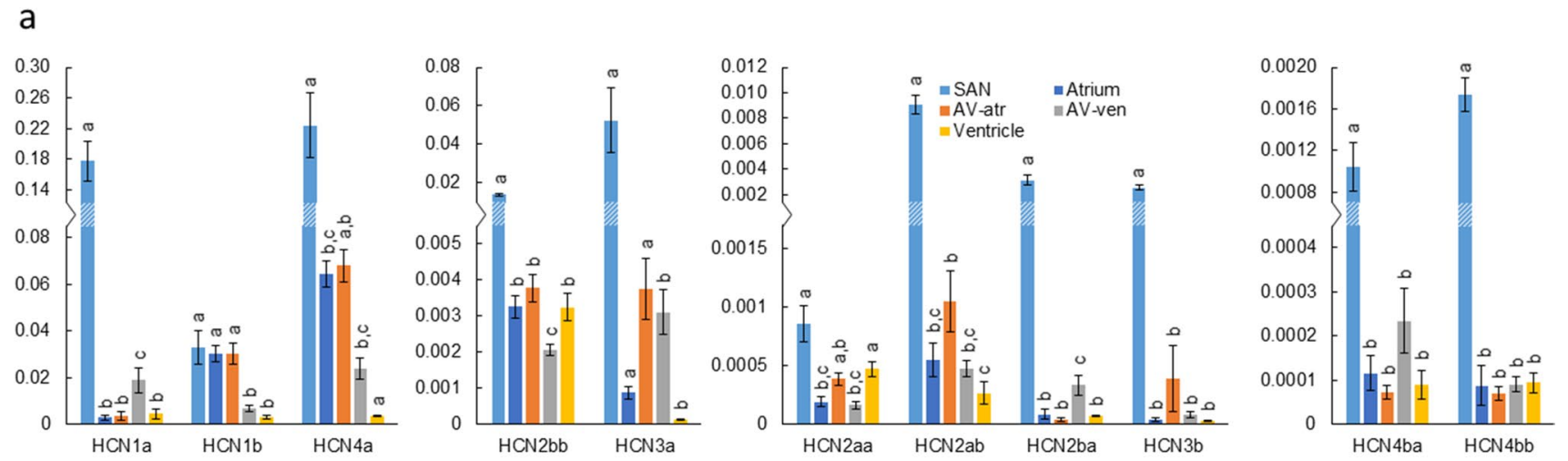

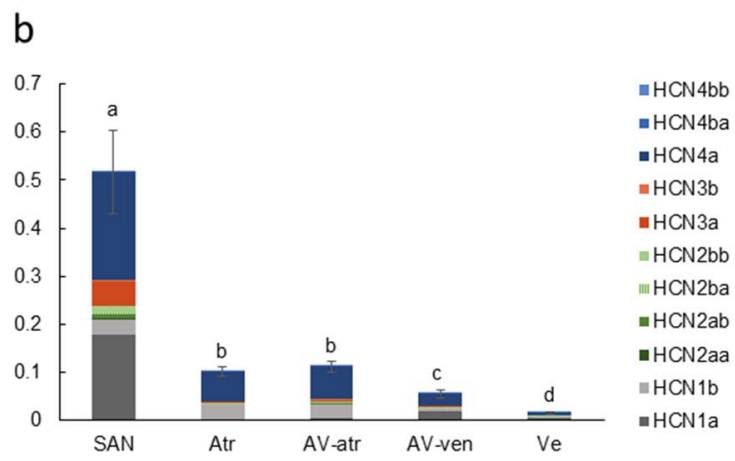

Fig. 10 Pacemaker channels. a Transcript expression of HCN genes encoding pacemaker channels normalized to the expression of reference gene DnaJA2 ( $n=5$, mean \pm S.E.M.). All known HCN isoforms of rainbow trout are included. Note the different $y$-axis scales of the

cells, which may prevent ventricular excitation (Vornanen 2020). In the zebrafish heart, the AV canal appears to be connected to the endocardial trabeculae by two specific tracts, whereas the contact of the AV canal with the outer compact myocardium seems to be blocked by an insulating wedge of connective tissue (Sedmera et al. 2003; Icardo and Colvee 2011). The role of the contact area between the AV canal and ventricular trabeculae in heat-induced ventricular bradycardia should be further investigated.

Although the morphology and histology of the fish AV area is fairly well known, the cell types that make up the myocardial tissue of the AV canal are less well elucidated (Santer and Cobb 1972; Sedmera et al. 2003; Icardo and Colvee 2011; Icardo 2017). In mammals, myocytes of the AV tissue are traditionally classified based on either their morphological or electrophysiological characteristics. Morphologically mammalian AV myocytes are described in three major categories: rod-shaped, ovoid and spindle-shaped cells (Anderson 1972; Munk et al. 1996; Ren et al. 2006). Three morphologically distinct myocyte types (star-, spider- and spindle-shaped cells) were identified in the rainbow trout AV tissue. However, based on electrophysiological properties, only two types of myocytes could be distinguished, which

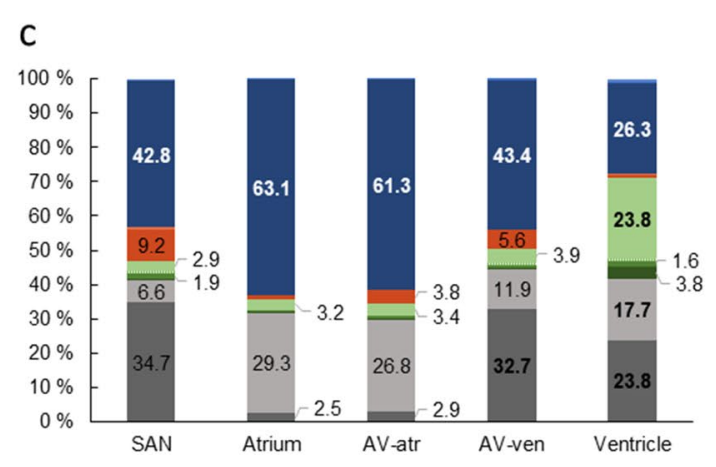

diagrams. b Total transcript expression of $\mathrm{HCN}$ isoforms in the cardiac compartments. c Relative proportion (\%) of each HCN isoform in cardiac compartments

were classified as either nodal AV myocytes or transitional AV myocytes. The star- and spider-shaped myocytes were generally nodal AV myocytes in their electrophysiological characteristics, whereas the spindle-shaped myocytes could electrophysiologically be either nodal or transitional $\mathrm{AV}$ myocytes. In this respect, trout AV cells are similar to mammalian AV cells whose electrophysiological phenotype cannot be reliably determined from their cellular morphology (Munk et al. 1996; McGuire et al. 1996). Since electrophysiological properties of trout AV cells cannot be inferred from their light microscopic appearance, their classification must be based on electrophysiological properties.

\section{Electrophysiological properties of trout AV myocytes}

Cardiomyocytes within the AV tissue are surrounded by considerable amount of connective tissue (Icardo and Colvee 2011), and therefore, isolation of AV cells requires a much longer digestion protocol than atrial and ventricular myocytes. Therefore, when isolating trout AV myocytes, the $\mathrm{AV}$ region was subjected to additional $20 \mathrm{~min}$ of enzymatic digestion after finishing the perfusion of the whole heart. 
Atrial and ventricular myocytes of the rainbow trout heart do not tolerate such long digestion period and are likely to die. Thus, we assume that nodal and transitional cells obtained from the AV region of the rainbow trout heart represent real AV myocytes, not potentially contaminating atrial or ventricular myocytes.

APs of the vertebrate AV node (AVN) are slowly rising and $\mathrm{V}_{\text {rest }}$ is less negative and AP amplitude smaller than in atrial and ventricular muscles (Hoffman et al. 1959; Billette 1987). The differences in AP shape are due to differences in ion channel composition and ion current characteristics of the nodal tissues (George et al. 2017). Moreover, the mammalian atrioventricular node (AVN) is divided into three regions based on the shape of AP: atrio-nodal (AN), nodal (N) and nodal-His (NH) cells (De Carvalho and De Almeida 1960). N cells are "real" nodal cells found in the compact node, whereas AN and NH myocytes are transitional cells located in the transitional zone and penetrating the bundle, respectively (Munk et al. 1996; Greener et al. 2009). The mammalian $\mathrm{N}$ cells are characterized by relatively depolarized $V_{\text {rest }}$, diastolic depolarization, slow rate of AP upstroke and ability to spontaneous pacemaking, whereas $\mathrm{AN}$ and $\mathrm{NH}$ cells have intermediate properties between atrial and nodal myocytes, i.e., having a fast rate of AP upstroke and a stable, negative $V_{\text {rest }}$ (Greener et al. 2009, 2011; Dobrzynski et al. 2013; Billette and Tadros 2019). Cardiomyocyte isolated from the rainbow trout $\mathrm{AV}$ region seemed to belong to either nodal AV myocytes or transitional AV myocytes, perhaps corresponding mammalian $\mathrm{N}$ and $\mathrm{AN} / \mathrm{NH}$ cells, respectively. The trout nodal myocytes had a tiny $\mathrm{I}_{\mathrm{K} 1}$ which meant they were unable to maintain a negative $V_{\text {rest }}$ typical of atrial and ventricular myocytes. Importantly, the highly depolarized value of $\mathrm{V}_{\text {rest }}$, measured with a current clamp in nodal cells, is an artifact due to the inward leakage current that makes the cell depolarized when $\mathrm{I}_{\mathrm{K} 1}$ is tiny. Further studies using sharp microelectrodes should find the true $V_{\text {rest }}$ values typical of these cells. The nodal myocytes always lacked $\mathrm{I}_{\mathrm{Na}}$ but had a robust $\mathrm{I}_{\mathrm{Ca}}$ characterized by the peak current at about $-20 \mathrm{mV}$ and low sensitivity to nifedipine. Since the RT-PCR data showed a high expression level of $\mathrm{Ca}_{\mathrm{V}} 3.1 \mathrm{a}$ (CACNA1Ga) transcripts, it can be assumed that this current is a T-type $\mathrm{Ca}^{2+}$ current $\left(I_{\mathrm{CaT}}\right)$, although further experiments are needed to clarify this point. It should be noted, however, that also $\mathrm{I}_{\mathrm{CaL}}$ was expressed in AV node cells. Indeed, the above characteristics of trout nodal cells resemble those of the mammalian $\mathrm{N}$ cells, where $\mathrm{I}_{\mathrm{K} 1}$ is small, $\mathrm{I}_{\mathrm{Na}}$ is absent and AP upstroke is generated by $I_{\mathrm{CaL}} / I_{\mathrm{CaT}}$ (George et al. 2017). The most notable difference in electrophysiological properties between trout and mammalian AV nodal tissues is perhaps the total absence of $\mathrm{I}_{\mathrm{f}}$ in the nodal cells of the trout heart. Unlike trout nodal cells, most mammalian $\mathrm{N}$ cells have the hyperpolarization-activated current $\left(I_{\mathrm{f}}\right)$ (Noma et al. 1980; Munk et al. 1996). The electrophysiological properties of the trout AV nodal cells are suitable for slow AP conduction (absence of $I_{\mathrm{Na}}$ ) and pacemaking activity (depolarized $V_{\text {rest }}$ and virtual absence of $I_{\mathrm{K} 1}$ ), although the ionic basis of the pacemaking remains open in the absence of $I_{\mathrm{f}}$. Despite the distinct differences in morphological structure of the AV tissue between mammalian and fish hearts (bundle or node vs. canal), the cellular diversity and functional properties seem to be similar.

The transitional AV myocytes have a prominent $I_{\mathrm{K} 1}$ and a stable negative $V_{\text {rest }}$. Unlike the nodal cells, they have $I_{\mathrm{Na}}$ but lack $I_{\mathrm{CaT}}$. These features make transitional AV cells more like working ventricular myocytes but can be distinguished from them by a lower density of $I_{\mathrm{K}}, I_{\mathrm{K} 1}$, and almost fourfold lower density of $\mathrm{I}_{\mathrm{Na}}$. The most striking difference between transitional AV cells and working atrial myocytes is the higher $I_{\mathrm{K} 1}$ density of the transitional AV cells. Therefore, transitional AV cells represent a specific type of fish cardiac myocytes, different from either nodal AV cells or working atrial and ventricular myocytes. The electrophysiological properties of trout transitional AV myocytes resemble those of mammalian AN cell where depolarization is achieved by $I_{\mathrm{Na}}, I_{\mathrm{f}}$ is absent and $I_{\mathrm{Ca}}$ is smaller than in $\mathrm{N}$ cells (Munk et al. 1996).

\section{Transcript expression of ion channel genes}

Although the ion channel expression profile of the mammalian cardiac conduction system is quite well known (Schram et al. 2002a; Gaborit et al. 2007; Greener et al. 2009, 2011; Chandler et al. 2009; Atkinson et al. 2013), practically nothing is known about it in fish hearts. Here, we provide the first look at the ion channel diversity of AV nodal tissue of teleost heart. One characteristic of fish ion channels is the large number of gene paralogs which originates from the whole genome duplications in the teleost lineage (Jegla et al. 2009; Glasauer and Neuhauss 2014; Hassinen et al. 2019). The high diversity of ion channel genes provides raw material for adaptation to different environmental conditions (Glasauer and Neuhauss 2014).

Regional differences existed in the expression of ion channel transcripts between AV tissue and other cardiac compartments of the rainbow trout heart. 13 out of 42 genes studied were expressed differently between $\mathrm{AV}$-ven region and the ventricle. In contrast, the transcript expression profile of the AV-atr was nearly identical with that of the atrium. Only 3 out of the 42 genes studied were significantly differently expressed between the atrium and the AV-atr: SCN4Aba showed lower, and CACNA1Ga and HCN3a higher mRNA expression in the AV-atr region than in the atrium. Thus, it is likely that the AV-atr sample was contaminated by atrial tissue. It should be noted, however, that vertebrate AVN is a heterogenous tissue and atrial myocytes are an integral part of the functional AV conduction system (George et al. 2017). 
The relatively depolarized $\mathrm{V}_{\text {rest }}$ of mammalian $\mathrm{N}$ cells (see "Electrophysiological properties of trout AV myocytes") is due to the total absence or low density of $I_{\mathrm{K} 1}$ current, which in turn is due to the low mRNA expression level of the main $\mathrm{I}_{\mathrm{K} 1}$ producing channel Kir2.1 (Greener et al. 2009, 2011; Dobrzynski et al. 2013). Similarly, the expression of the main ventricular Kir2 channel of the trout heart, Kir2.4, was lower in the AV-ven region than in the ventricle. The Kir2 expression correlates well with the smaller $\mathrm{I}_{\mathrm{K} 1}$ and less negative $V_{\text {rest }}$ of trout nodal cells. KCNH6/7 channels generate the $\mathrm{I}_{\mathrm{Kr}}$ the main repolarizing current of fish cardiac myocytes at AP plateau voltages, which regulate AP duration but are unlikely to be involved in maintaining $V_{\text {rest }}$ (Vornanen et al. 2002; Galli et al. 2009; Haverinen and Vornanen 2009; Abramochkin and Vornanen 2015; Filatova et al. 2019). KCNH6/7 expression was highest in the atrium and lowest in the AV-ven which correlates reasonably well with $\mathrm{I}_{\mathrm{K}}$ densities of atrial and AV nodal cells.

Although $I_{\mathrm{f}}$ current was not found in the cells of trout $\mathrm{AV}$ tissue, $\mathrm{HCN}$ channels were expressed to some extent in AV tissue (and all parts of the trout heart). Expression levels of the major HCN channels of the rainbow trout heart, HCN1a and $\mathrm{HCN} 4 \mathrm{a}$, were higher in the $\mathrm{AV}$-ven region than in the ventricle consistently with the spontaneous activity of the trout AV canal (Abramochkin et al. unpublished) (Stoyek et al. 2016). Since $I_{f}$ was not found in trout AV myocytes, $I_{f}$ may play a minor role in the spontaneous activity of the trout AV canal. The present findings are consistent with the histochemical studies of zebrafish heart; some polygonal HCN4positive cells are present in zebrafish AV region but in the absence of Islet-1, their identity as pacemaker cells remains open (Stoyek et al. 2016). In humans, rabbits and rats, the HCN4 channel is abundantly expressed in the AVN (Yoo et al. 2006; Greener et al. 2009, 2011). However, even in mammalian hearts, not all AVN myocytes express $\mathrm{I}_{\mathrm{f}}$ (Noma et al. 1980; Munk et al. 1996; Nikmaram et al. 2008; Cheng et al. 2011). It is clear that more detailed studies are needed on the ionic mechanism of the nodal cells of the fish heart.

Slow rate of AP upstroke is typical for $\mathrm{N}$ cells of the mammalian AVN, which is due to low expression level of $\mathrm{Na}^{+}$channels (Yoo et al. 2006). AP upstroke in mammalian AVN myocytes is achieved by $\mathrm{I}_{\mathrm{CaL}}$ rather than $\mathrm{I}_{\mathrm{Na}}$ (Dobrzynski et al. 2013). In terms of $\mathrm{Na}^{+}$and $\mathrm{Ca}^{2+}$ channels/currents, the AV tissue of the trout heart is largely similar to the mammalian $\mathrm{N}$ cells. In trout, a small $\mathrm{I}_{\mathrm{Na}}$ existed in transitional AV myocytes, whereas it was completely absent in nodal cells. In addition, the mRNA expression levels of $\mathrm{Na}^{+}$channel isoforms SCN4Aba and SCN5LAba were lower in the AV-ven region than in the ventricle. In the human, $\mathrm{AVN} \mathrm{Ca}_{\mathrm{v}} 1.3$ (CACNA1D) and $\mathrm{Ca}_{\mathrm{v}} 3.1$ (CACNA1G) are highly expressed (Greener et al. 2011). In the trout heart, $\mathrm{Ca}_{\mathrm{v}} 3.1$ was also more abundant in the $\mathrm{AV}$-ven region than in the ventricle. In contrast, $\mathrm{Ca}_{\mathrm{v}} 1.3$ isoform was more weakly expressed in the AV-ven zone than in the working ventricular myocardium. The abundant expression of T-type $\mathrm{Ca}^{2+}$ channel genes correlates well with the electrophysiological data indicating the presence of two $\mathrm{Ca}^{2+}$ current types in nodal cells.

The vertebrate AVN acts as an auxiliary pacemaker if SAN function fails, albeit with a slower intrinsic rate (Meijler and Janse 1988; Stoyek et al. 2016; Billette and Tadros 2019). There are significant similarities in the ionic bases of AP formation between SA and AV tissue of the vertebrate heart, although ion currents of the AV tissue are not known as well as those of the SAN (Schram et al. 2002b; Marionneau et al. 2005; Greener et al. 2009). Therefore, trout AV canal and SAN might be expected to have some common electrophysiological features. Consistent with its putative role in cardiac pacemaking, the expression of HCN channels in the SAN was several-fold higher than in other parts of the trout heart. In the trout AV-atr, HCN expression was only about $20 \%$ of the SAN level. This difference in $\mathrm{HCN}$ channel expression between trout SA and AV tissue is very similar to that of the mouse heart (Marionneau et al. 2005). It should be noted, however, that although HCN channels are expressed in the SAN of the brown trout (Salmo trutta), the $\mathrm{I}_{\mathrm{f}}$ current is very small and detected only in a minor subpopulation of SAN cells (Hassinen et al. 2017). The rate of AP upstroke in vertebrate nodal tissues is based on $\mathrm{Ca}^{2+}$ currents and is, therefore, much slower than in working atrial and ventricular myocytes (Irisawa 1978). Consistent with this $\mathrm{Na}^{+}$channel expression in AV-ven was low, but quite surprisingly, $\mathrm{Na}^{+}$ channel transcripts in the SAN were much higher than in any other part of the trout heart. Sutcliffe et al. (Sutcliffe et al. 2020) also found a high transcript expression of $\mathrm{Na}^{+}$ channels in rainbow trout SAN. The abundance of $\mathrm{Na}^{+}$ channels is probably due to the abundant neuronal tissue which tightly surrounds the primary pacemaker of rainbow trout heart (Yamauchi and Burnstock 1968; Haverinen and Vornanen 2007). Islet-1 (ISL1) is a transcription factor involved in cardiogenesis and a marker of pacemaker cells in zebrafish SAN (Tessadori et al. 2012; Kelder et al. 2015; Stoyek et al. 2016). In rainbow trout heart, ISL1 isoforms were expressed mainly in SAN, with very low expression level ( $\leq 1.5 \%$ of the SAN level) in the AV canal and other parts of the heart. While this is consistent with its role in the fish SAN in supporting pacemaker activity via maintenance of the gene expression profile of the SAN cells, it may have little role in AV nodal tissue (Vedantham et al. 2015). Both L- and T-type $\mathrm{Ca}^{2+}$ channels were expressed in trout SAN, transcripts of CACNA1Daa, -Dab, -Dba, $-\mathrm{Ga},-\mathrm{Gb}$ and $-\mathrm{Ha}$ being more abundant in SAN than in atrium. This is in accordance with mammalian SAN where CACNA1D and CACNA1G are more abundant than in atrium (Chandler et al. 2009). 


\section{Limitations and perspectives}

Although the current study provides the first glimpse to the ionic function of the fish AV canal, more research is needed to specify the electrophysiological properties and ion channel composition of nodal and transitional myocytes. In particular, transcript expression of ion channels should be measured from pure AV myocyte samples collected by microdissection, or alternatively in situ hybridization should be used to localize gene expression. However, ion channels are often expressed at low levels which makes the in situ approach difficult. Connexins form gap junctions which have an important role in mammalian AVN function and deserve research in fish as well. This will be, however, a tedious task because there are at least 77 connexin genes in the rainbow trout genome (GenBank). However, further molecular studies and related functional experiments at the whole tissue level should be pursued to understand AV tissue function in thermal responses of the fish heart.

Acknowledgements The authors thank Anita Kervinen for her assistance in maintenance of the fish and preparing solutions for electrophysiological experiments.

Author contributions $\mathrm{MH}$ has designed and done all molecular studies and histological work. DVA and MV designed the electrophysiological studies. ID and DVA made the electrophysiological experiments. DVA and $\mathrm{MH}$ have prepared the figures for electrophysiological and histological/molecular data, respectively. All the authors have participated in manuscript writing.

Funding Open Access funding provided by University of Eastern Finland (UEF) including Kuopio University Hospital. This work was supported by a research grant from the Academy of Finland to M.V. (Grant number 15051) and by the Interdisciplinary Scientific and Educational School of Moscow University "Molecular Technologies of the Living Systems and Synthetic Biology" to DA

Availability of data and material Gene sequences can be found in GenBank.

\section{Compliance with ethical standards}

Conflict of interest/Competing interest The authors declare that they have no conflict of interest.

Ethics approval All applicable international, national, and/or institutional guidelines for the care and use of animals were followed. All experiments were made with the consent of the national committee for animal experimentation (permission ESAVI/8877/2019).

Open Access This article is licensed under a Creative Commons Attribution 4.0 International License, which permits use, sharing, adaptation, distribution and reproduction in any medium or format, as long as you give appropriate credit to the original author(s) and the source, provide a link to the Creative Commons licence, and indicate if changes were made. The images or other third party material in this article are included in the article's Creative Commons licence, unless indicated otherwise in a credit line to the material. If material is not included in the article's Creative Commons licence and your intended use is not permitted by statutory regulation or exceeds the permitted use, you will need to obtain permission directly from the copyright holder. To view a copy of this licence, visit http://creativecommons.org/licenses/by/4.0/.

\section{References}

Abramochkin DV, Vornanen M (2015) Seasonal acclimatization of the cardiac potassium currents $\left(\mathrm{I}_{\mathrm{K} 1}\right.$ and $\left.\mathrm{I}_{\mathrm{Kr}}\right)$ in an arctic marine teleost, the navaga cod (Eleginus navaga). J Comp Physiol B 185:883-890

Abramochkin DV, Hassinen M, Vornanen M (2018) Transcripts of Kv7.1 and MinK channels and slow delayed rectifier $\mathrm{K}^{+}$current $\left(\mathrm{I}_{\mathrm{Ks}}\right)$ are expressed in zebrafish (Danio rerio) heart. Pflüg Arch 470:1753-1764

Anderson RH (1972) Histologic and histochemical evidence concerning the presence of morphologically distinct cellular zones within the rabbit atrioventricular node. Anat Rec 173:7-23

Arbel ER, Liberthson R, Langendorf R, Pick A, Lev M, Fishman AP (1977) Electrophysiological and anatomical observations on the heart of the African lungfish. Am J Physiol 232:H24-H34

Atkinson AJ, Logantha SJ, Hao G, Yanni J, Fedorenko O, Sinha A, Gilbert SH, Benson AP, Buckley DL, Anderson RH, Boyett MR, Dobrzynski H (2013) Functional, anatomical, and molecular investigation of the cardiac conduction system and arrhythmogenic atrioventricular ring tissue in the rat heart. J Am Heart Assoc 2:e000246

Badr A, El-Sayed MF, Vornanen M (2016) Effects of seasonal acclimatization on temperature-dependence of cardiac excitability in the roach, Rutilus rutilus. J Exp Biol 219:1495-1504

Barros TP, Alderton WK, Reynolds HM, Roach AG, Berghmans S (2008) Zebrafish: an emerging technology for in vivo pharmacological assessment to identify potential safety liabilities in early drug discovery. Br J Pharmacol 154:1400-1413

Billette J (1987) Atrioventricular nodal activation during periodic premature stimulation of the atrium. Am J Physiol 252:H163-H177

Billette J, Tadros R (2019) An integrated overview of AV node physiology. PACE Pacing Clin Electrophysiol 42:805-820

Cassar S, Adatto I, Freeman JL, Gamse JT, Iturria I, Lawrence C, Muriana A, Peterson RT, Van Cruchten S, Zon LI (2019) Use of zebrafish in drug discovery toxicology. Chem Res Toxicol. 33:95-118

Chandler NJ, Greener ID, Tellez JO, Inada S, Musa H, Molenaar P, Difrancesco D, Baruscotti M, Longhi R, Anderson RH, Billeter R, Sharma V, Sigg DC, Boyett MR, Dobrzynski H (2009) Molecular architecture of the human sinus node: insights into the function of the cardiac pacemaker. Circulation 119:1562-1575

Cheng H, Smith GL, Hancox JC, Orchard CH (2011) Inhibition of spontaneous activity of rabbit atrioventricular node cells by KB-R7943 and inhibitors of sarcoplasmic reticulum $\mathrm{Ca}^{2+}$ ATPase. Cell Calcium 49:56-65

De Carvalho A, P., De Almeida DF, (1960) Spread of activity through the atrioventricular node. Circ Res 8:801-809

Dobrzynski H, Anderson RH, Atkinson A, Borbas Z, D’Souza A, Fraser JF, Inada S, Logantha SJ, Monfredi O, Morris GM, Moorman AF, Nikolaidou T, Schneider H, Szuts V, Temple IP, Yanni J, Boyett MR (2013) Structure, function and clinical relevance of the cardiac conduction system, including the atrioventricular ring and outflow tract tissues. Pharmacol Ther 139:260-288

Filatova TS, Abramochkin DV, Shiels HA (2019) Thermal acclimation and seasonal acclimatization: a comparative study of 
cardiac response to prolonged temperature change in shorthorn sculpin. J Exp Biol. https://doi.org/10.1242/jeb.202242

Gaborit N, Le Bouter S, Szuts V, Varro A, Escande D, Nattel S, Demolombe S (2007) Regional and tissue specific transcript signatures of ion channel genes in the non-diseased human heart. J Physiol 582:675-693

Galli GL, Lipnick MS, Block BA (2009) Effect of thermal acclimation on action potentials and sarcolemmal $\mathrm{K}^{+}$channels from Pacific bluefin tuna cardiomyocytes. Am J Physiol 297:R502-R509

George SA, Faye NR, Murillo-Berlioz A, Lee KB, Trachiotis GD, Efimov IR (2017) At the atrioventricular crossroads: dual pathway electrophysiology in the atrioventricular node and its underlying heterogeneities. Arrhythm Electrophysiol Rev 6:179-185

Glasauer SMK, Neuhauss SCF (2014) Whole-genome duplication in teleost fishes and its evolutionary consequences. Mol Genet Genomics 289:1045-1060

Greener ID, Tellez JO, Dobrzynski H, Yamamoto M, Graham GM, Billeter R, Boyett MR (2009) Ion channel transcript expression at the rabbit atrioventricular conduction axis. Circ Arrhythm Electrophysiol 2:305-315

Greener ID, Monfredi O, Inada S, Chandler NJ, Tellez JO, Atkinson A, Taube MA, Billeter R, Anderson RH, Efimov IR, Molenaar P, Sigg DC, Sharma V, Boyett MR, Dobrzynski H (2011) Molecular architecture of the human specialised atrioventricular conduction axis. J Mol Cell Cardiol 50:642-651

Hassinen M, Haverinen J, Vornanen M (2008) Electrophysiological properties and expression of the delayed rectifier potassium (ERG) channels in the heart of thermally acclimated rainbow trout. Am J Physiol 295:R297-R308

Hassinen M, Laulaja S, Paajanen V, Haverinen J, Vornanen M (2011) Thermal adaptation of the crucian carp (Carassius carassius) cardiac delayed rectifier current, $\mathrm{I}_{\mathrm{Ks}}$, by homomeric assembly of Kv7.1 subunits without MinK. Am J Physiol 301:R255-R2665

Hassinen M, Haverinen J, Hardy ME, Shiels HA, Vornanen M (2015) Inward rectifier potassium current $\left(\mathrm{I}_{\mathrm{K} 1}\right)$ and Kir2 composition of the zebrafish (Danio rerio) heart. Pflüg Arch 467:2437-2446

Hassinen M, Haverinen J, Vornanen M (2017) Small functional $I_{f}$ current in sinoatrial pacemaker cells of the brown trout (Salmo trutta fario) heart despite strong expression of $\mathrm{HCN}$ channel transcripts. Am J Physiol 313:R711-R722

Hassinen M, Korajoki H, Abramochkin DV, Krivosheya P, Vornanen M (2019) Transcript expression of inward rectifier potassium channels of Kir2 subfamily in Arctic marine and freshwater fish species. J Comp Physiol B 189:735-749

Haverinen J, Vornanen M (2007) Temperature acclimation modifies sinoatrial pacemaker mechanism of the rainbow trout heart. Am J Physiol 292:R1023-R1032

Haverinen J, Vornanen M (2009) Responses of action potential and $\mathrm{K}^{+}$currents to temperature acclimation in fish hearts: phylogeny or thermal preferences? Physiol Biochem Zool 82:468-482

Haverinen J, Vornanen M (2020) Reduced ventricular excitability causes atrioventricular block and depression of heart rate in fish at critically high temperatures. J Exp Biol. https://doi. org/10.1242/jeb.225227

Haverinen J, Egginton S, Vornanen M (2014) Electrical excitation of the heart in a basal vertebrate, the European river lamprey (Lampetra fluviatilis). Physiol Biochem Zool 87:817-828

Hoffman BF, De Carvalho AP, Mello WC, Cranefield PF (1959) Electrical activity of single fibers of the atrioventricular node. Circ Res 7:11-18

Icardo JM (2017) Heart morphology and anatomy. In: Gamperl AK, Gillis TE (eds) Fish Physiology. Elsevier, London, pp 1-54

Icardo JM, Colvee E (2011) The atrioventricular region of the teleost heart. A distinct heart segment. Anat Rec 294:236-242
Irisawa H (1978) Comparative physiology of the cardiac pacemaker mechanism. Physiol Rev 58:461-498

Jegla TJ, Zmasek CM, Batalov S, Nayak SK (2009) Evolution of the human ion channel set. Comb Chem High Throughput Screen $12: 2-23$

Jensen B, Boukens BJD, Postma AV, Gunst QD, van den Hoff MJ, Moorman AFM, Wang T, Christoffels VM (2012) Identifying the evolutionary building blocks of the cardiac conduction system. PLoS ONE 7:e44231

Keith A, Flack M (1907) The form and nature of the muscular connections between the primary divisions of the vertebrate heart. $\mathrm{J}$ Anat Physiol 41:172-189

Kelder TP, Vicente-Steijn R, Harryvan TJ, Kosmidis G, Gittenbergerde Groot AC, Poelmann RE, Schalij MJ, DeRuiter MC, Jongbloed MR (2015) The sinus venosus myocardium contributes to the atrioventricular canal: potential role during atrioventricular node development? J Cell Mol Med 19:1375-1389

Marionneau C, Couette B, Liu J, Li H, Mangoni ME, Nargeot J, Lei M, Escande D, Demolombe S (2005) Specific pattern of ionic channel gene expression associated with pacemaker activity in the mouse heart. J Physiol 562:223-234

McGuire MA, de Bakker JMT, Vermeulen JT, Moorman AFM, Loh P, Thibault B, Vermeulen JLM, Becker AE, Janse MJ (1996) Atrioventricular junctional tissue: discrepancy between histological and electrophysiological characteristics. Circulation 94:571-577

McWilliam JA (1885) On the structure and rhythm of the heart in fishes, with especial reference to the heart of the Eel. J Physiol 6(4-5):192-292

Meijler FL, Janse MJ (1988) Morphology and electrophysiology of the mammalian atrioventricular node. Physiol Rev 68:608-647

Milan DJ, Giokas AC, Serluca FC, Peterson RT, MacRae CA (2006) Notch $1 \mathrm{~b}$ and neuregulin are required for specification of central cardiac conduction tissue. Development 133:1125-1132

Monteiro DA, Taylor EW, McKenzie DJ, Rantin FT, Kalinin AL (2020) Interactive effects of mercury exposure and hypoxia on ECG patterns in two Neotropical freshwater fish species: Matrinxã, Brycon amazonicus and traíra, Hoplias malabaricus. Ecotoxicology 29:375-388

Munk AA, Adjemian RA, Zhao J, Ogbaghebriel A, Shrier A (1996) Electrophysiological properties of morphologically distinct cells isolated from the rabbit atrioventricular node. J Physiol 493:801-818

Nair MGK (1976) Some observations on the anatomy of the heart of the African lung fish, Protopterus aethiopicus Heckel. Proc Indian Acad Sci 84:6-11

Nikmaram MR, Liu J, Abdelrahman M, Dobrzynski H, Boyett MR, Lei M (2008) Characterization of the effects of ryanodine, TTX, E-4031 and 4-AP on the sinoatrial and atrioventricular nodes. Prog Biophys Mol Biol 96:452-464

Noma A, Irisawa H, Kokubun S, Kotake H, Nishimura M, Watanabe Y (1980) Slow current systems in the A-V node of the rabbit heart. Nature 285:228-229

Ren FX, Niu XL, Ou Y, Han ZH, Ling FD, Zhou SS, Li YJ (2006) Morphological and electrophysiological properties of single myocardial cells from Koch triangle of rabbit heart. Chin Med J (Engl) 119:2075-2084

Santer RM, Cobb JLS (1972) The fine structure of the heart of the teleost, Pleuronectes platessa L. Z Zellforsch Mik Ana 131:1-14

Sarmah S, Marrs JA (2016) Zebrafish as a vertebrate model system to evaluate effects of environmental toxicants on cardiac development and function. Int J Mol Sci 17:2123

Schram G, Pourrier M, Melnyk P, Nattel S (2002a) Differential distribution of cardiac ion channel expression as a basis for regional specialization in electrical function. Circ Res 90:939-950

Sedmera D, Reckova M, deAlmeida A, Sedmerova M, Biermann M, Volejnik J, Sarre A, Raddatz E, McCarthy RA, Gourdie RG, 
Thompson RP (2003) Functional and morphological evidence for a ventricular conduction system in zebrafish and Xenopus hearts. Am J Physiol 284:H1152-H1160

Solc D (2007) The heart and heart conducting system in the kingdom of animals: A comparative approach to its evolution. Exp Clin Cardiol 12:113-118

Stoyek MR, Quinn TA, Croll RP, Smith FM (2016) Zebrafish heart as a model to study the integrative autonomic control of pacemaker function. Am J Physiol 311:H676-H688

Sutcliffe RL, Li S, Gilbert MJH, Schulte PM, Miller KM, Farrell AP (2020) A rapid intrinsic heart rate resetting response with thermal acclimation in rainbow trout, Oncorhynchus mykiss. J Exp Biol 223:jeb215210

Tessadori F, van Weerd JH, Burkhard SB, Verkerk AO, de Pater E, Boukens BJD, Vink A, Christoffels VM, Bakkers J (2012) Identification and functional characterization of cardiac pacemaker cells in zebrafish. PLoS ONE 7:e47644

Vedantham V, Galang G, Evangelista M, Deo RC, Srivastava D (2015) RNA sequencing of mouse sinoatrial node reveals an upstream regulatory role for Islet-1 in cardiac pacemaker cells. Circ Res 116:797-803

Vornanen M (1997) Sarcolemmal Ca influx through L-type Ca channels in ventricular myocytes of a teleost fish. Am J Physiol 272:R1432-R1440

Vornanen M (2017) Electrical excitability of the fish heart and its autonomic regulation. In: Gamperl AK, Gillis TE, Farrell AP, Brauner CJ (eds) Fish physiology. The cardiovascular physiology. Morphology, control and function. Elsevier, London, pp 99-153
Vornanen M (2020) Feeling the heat: source-sink mismatch as a mechanism underlying the failure of thermal tolerance. J exp Biol 223:16

Vornanen M, Ryökkynen A, Nurmi A (2002) Temperature-dependent expression of sarcolemmal $\mathrm{K}^{+}$currents in rainbow trout atrial and ventricular myocytes. Am J Physiol 282:R1191-R1199

Vornanen M, Hassinen M, Koskinen H, Krasnov A (2005) Steady-state effects of temperature acclimation on the transcriptome of the rainbow trout heart. Am J Physiol 289:R1177-R1184

Vornanen M, Hassinen M, Haverinen J (2011) Tetrodotoxin sensitivity of the vertebrate cardiac $\mathrm{Na}^{+}$current. Mar Drugs 9:2409-2422

Vornanen M, Haverinen J, Egginton S (2014) Acute heat tolerance of cardiac excitation in the brown trout (Salmo trutta fario). J Exp Biol 217:299-309

Yamauchi A, Burnstock G (1968) An electronmicroscopic study on the innervation of the trout heart. J Comp Neurol 132:567-588

Yoo S, Dobrzynski H, Fedorov VV, Xu SZ, Yamanushi TT, Jones SA, Yamamoto M, Nikolski VP, Efimov IR, Boyett MR (2006) Localization of $\mathrm{Na}^{+}$channel isoforms at the atrioventricular junction and atrioventricular node in the rat. Circulation 114:1360-1371

Publisher's Note Springer Nature remains neutral with regard to jurisdictional claims in published maps and institutional affiliations. 